Portland State University

PDXScholar

Business Faculty Publications and

Presentations

The School of Business

2-2013

\title{
Director Ownership, Governance, and Performance
}

Sanjai Bhagat

University of Colorado at Boulder

Brian Bolton

Portland State University, bbolton@pdx.edu

Follow this and additional works at: https://pdxscholar.library.pdx.edu/busadmin_fac

Part of the Corporate Finance Commons, and the Finance and Financial Management Commons

Let us know how access to this document benefits you.

\section{Citation Details}

Bhagat, S., \& Bolton, B. (2013). Director Ownership, Governance, and Performance. Journal of Financial \& Quantitative Analysis, 48(1), 105-135. doi:10.1017/S0022109013000045

This Article is brought to you for free and open access. It has been accepted for inclusion in Business Faculty Publications and Presentations by an authorized administrator of PDXScholar. Please contact us if we can make this document more accessible: pdxscholar@pdx.edu. 


\title{
Director Ownership, Governance, and Performance
}

\author{
Sanjai Bhagat and Brian Bolton*
}

\begin{abstract}
We study the impact of the Sarbanes-Oxley Act on the relationship between corporate governance and company performance. We consider 5 measures of corporate governance during the period 1998-2007. We find a significant negative relationship between board independence and operating performance during the pre-2002 period, but a positive and significant relationship during the post-2002 period. Our most important contribution is a proposal of a governance measure, namely, dollar ownership of the board members, that is simple, intuitive, less prone to measurement error, and not subject to the problem of weighting a multitude of governance provisions in constructing a governance index.
\end{abstract}

\section{Introduction}

The corporate scandals of the early 2000s, including Enron, Worldcom, Tyco, and others, led to a wave of regulation aimed at improving the corporate governance environment. A common feature of this was the implementation of guidelines concerning the independence of the members of the board of directors. For example, the Sarbanes-Oxley Act of 2002 (SOX) mandated that all members of a listed firm's audit committee must be independent. Soon thereafter, both the New York Stock Exchange and the NASDAQ Stock Market required all listed companies to have a majority of independent directors.

The regulatory and institutional focus on board independence is surprising given that most of the prior academic research found no statistical relationship and, in many cases, found a negative relationship, between board independence and firm performance. The above research, however, focuses on a time period prior to this recent wave of regulation aimed at increasing board independence on

\footnotetext{
*Bhagat, sanjai.bhagat@colorado.edu, Leeds School of Business, University of Colorado at Boulder, UCB 419, Boulder, CO 80309; Bolton, bbolton@pdx.edu, School of Business Administration, Portland State University, PO Box 751, Portland, OR 97207. We thank Yaniv Grinstein (the referee), Paul Malatesta (the editor), Andrew Metrick, and seminar participants at Harvard University and American Finance Association meetings for constructive comments on a previous draft of this paper. The Internet Appendix and Excel files that contain the data used in this study can be found at the JFQA Web site (www.jfqa.org).
} 
boards and audit committees. Even those studies that do include some post-2002 data include mostly pre-2002 data, so it is difficult to separate the findings into pre- and post-regulation relationships.

Our paper fills this gap in the literature: We study the relationships between various measures of corporate governance (especially board independence) and firm performance during the period 1998-2007. We explicitly separate the sample period into pre- and post-2002 subperiods to focus on the effects of the regulation. While we confirm the negative relationship between board independence and firm performance (that most prior research has identified) for the pre-2002 period, this result is reversed for the post-2002 period. During the years 2003-2007, greater board independence is positively correlated with operating performance. In other tests, we find that this result is driven by firms that increase their number of independent directors. An event study provides independent evidence supportive of the above results - specifically, when a company goes from being noncompliant to being compliant with SOX's board independence requirement, the market response is significantly positive. The above findings are consistent with and supportive of the event-study results of Chhaochharia and Grinstein (2007) and DeFond, Hann, and $\mathrm{Hu}$ (2005). Chhaochharia and Grinstein find that firms that were less compliant with the rules imposed by SOX and the exchanges earned more positive abnormal returns on the announcement of the rules. DeFond et al. document a positive stock market reaction when a director with accounting expertise is appointed to the audit committee.

While SOX specifically affects board independence, perhaps the increased scrutiny of all firms' corporate governance environments forces firms to implement better corporate governance practices, regardless of how those governance practices are measured. ${ }^{1}$ As such, board independence is not the only measure of governance that we consider. We find that the dollar value of director stock ownership is positively related to operating performance both pre- and post-2002. We also find that whether or not a firm's chief executive officer (CEO) is also the board chair is negatively related to operating performance throughout the sample period. These findings are consistent with prior literature. We also consider 2 popular corporate governance indices: the G-Index of Gompers, Ishii, and Metrick (GIM) (2003) and the E-Index of Bebchuk, Cohen, and Ferrell (BCF) (2009). During 1998-2001, both the G-Index and the E-Index suggest a positive and significant relation between good governance and performance; these findings are consistent with the extant literature. However, during 2003-2007, the G-Index suggests a negative and significant relation between good governance and performance. Also, during 2003-2007, the E-Index suggests an inconsistent relation between good governance and performance.

As many prior studies note, the relationship between corporate governance and company performance is plagued by endogeneity concerns. It is unclear whether performance causes governance or whether governance causes performance. To account for this, we utilize a 4-equation system to allow for governance, performance, ownership, and capital structure to be potentially endogenous. We

\footnotetext{
${ }^{1}$ For example, Brochet (2010) finds that Section 403 of SOX has brought about more timeliness and transparency in the communication of insider trading.
} 
adopt an instrumental variables (IV) approach to estimate the system of equations, checking for the validity and strength of our instruments and specification of the system of equations. In addition, as a robustness check we consider alternative methodologies less susceptible to the endogeneity concern (with consistent results).

Although most prior research has not found a positive relationship between board independence and firm performance prior to 2002, some research has found support for board independence in specific situations. Hermalin (2005) develop a model predicting that board independence provides greater oversight of managerial actions. Bhagat and Bolton (BB) (2008) find that firms with greater board independence are more likely to replace the CEO following periods of bad performance. We extend this CEO turnover test to our sample period and find this result persists in the post-2002 time period. In sum, these findings are consistent with the notion that the wave of corporate governance regulation that occurred during 2002 may have had some desired effect. Specifically, post-2002, companies whose boards are more independent are positively correlated with better operating performance.

In addition to studying the changing nature of corporate governance across the pre- and post-2002 subperiods, we make 5 additional contributions to the literature. First, consistent with the efficient market hypothesis, we show that none of the governance measures are correlated with current or future stock market performance, in contrast to the claims in papers such as GIM (2003) and BCF (2009). Second, we find that given poor firm performance, the probability of disciplinary management turnover is positively correlated with stock ownership of board members and board independence. However, given poor firm performance, the probability of disciplinary management turnover is negatively correlated with better governance measures as proposed by GIM and BCF. In other words, so called "better-governed firms" as measured by the GIM and BCF indices are less likely to experience disciplinary management turnover in spite of their poor performance. Third, we find that firms with greater stock ownership of board members and board independence are less likely to engage in a value-destroying activity, namely, acquisitions. On the other hand, better-governed firms as measured by the GIM and BCF indices are more likely to engage in acquisitions. Fourth, we show that firms that are not compliant with SOX have significantly higher abnormal returns upon becoming compliant than do noncompliant firms that stay noncompliant; this is consistent with and supportive of the results of Chhaochharia and Grinstein (2007) and DeFond et al. (2005). The most important contribution of this paper is our proposal of a governance measure, namely, dollar ownership of the board members, that is simple, intuitive, less prone to measurement error, and not subject to the problem of weighting a multitude of governance provisions in constructing a governance index. Consideration of this governance measure by future researchers would enhance the comparability of research findings with more robust progress in governance research.

The remainder of this paper is organized as follows: The next section discusses the relevant literature. Section III introduces our model specification and sample. Section IV presents the results on the relationship between corporate governance and company performance. Section $V$ discusses results of an 
event study where we focus on the announcement by sample firms of the nomination of additional independent directors that would enable the firm to comply with SOX's board independence requirement for the audit committee. Section VI considers the relationship between corporate governance, company performance, and CEO turnover. Section VII considers the relationship between corporate governance and merger and acquisition (M\&A) deals. Section VIII notes our conclusions.

\section{Corporate Governance and Board Independence}

The relationship between board independence and firm performance is one of the most studied relationships in the corporate governance literature. Hermalin and Weisbach (1991) find no relationship between board composition and performance (using Tobin's Q $(Q)$ as the performance measure). Agrawal and Knoeber (1996) study the interrelationships among 7 corporate governance mechanisms and find a negative relationship between independence and firm performance (as measured by $Q$ ). Bhagat and Black (2002), using a variety of performance measures, document that firms with more independent boards do not perform better. They also find that poorly performing firms are more likely to increase the number of independent directors, but that this does not improve performance. More recently, BB (2008) find a negative relationship between board independence and operating performance. The overwhelming majority of work finds that having a more independent board of directors does not lead to better performance and may actually lead to worse performance.

Adams and Ferreira (2007) introduce a model that suggests CEOs may be reluctant to share information with more independent boards, thereby decreasing shareholder value. This suggests that the requirements of SOX and the stock exchanges for firms to increase director independence may potentially be detrimental to firm value. Laux (2008) presents a model considering CEO turnover and board independence, and shows that greater board independence might be detrimental to the firm because independent boards might be too active in replacing the CEO and in formulating CEO compensation. Raheja (2005) looks at the board's monitoring role with respect to investment projects. In her model, inside directors have more knowledge of the firm's investments, so the optimal board structure will depend on the project verification costs to outsiders and private benefits from projects to insiders. This suggests greater board independence can be beneficial in some firms while being detrimental in other firms. Similarly, Coles, Daniel, and Naveen's (2008) work suggests that smaller and more independent boards may not be superior in all cases. Using data from 1997-2000, Gillan, Hartzell, and Starks (2003) show that firms with more powerful boards (or more independent boards) also have higher G-Index scores, suggesting that managers may become more entrenched to protect themselves from the oversight of an independent board. Finally, Chhaochharia and Grinstein (2007) find that firms that were less compliant with the rules imposed by SOX and the exchanges earned positive abnormal returns on the announcement of the rules, relative to firms that were more compliant. 
One common feature of these studies is that they mostly focus on boards and relationships prior to 2002. It is rare to see an exogenous shock to the corporate governance landscape, but the increased regulation of 2002 may be just the kind of event to provide a demarcation of corporate governance regimes. Section 301 of SOX mandates that the audit committees of public firms be comprised entirely of independent directors and that the audit committee contain at least one "finance expert." While firms could meet the independence requirement by removing affiliated directors from the board, some firms might have to add independent directors in order to meet the "finance expert" requirement. ${ }^{2}$ Furthermore, it stipulates that if a firm does not have a stand-alone audit committee, then the entire board functions as the audit committee and it, therefore, must be comprised entirely of outside directors. Subsequent to the passage of SOX, the New York Stock Exchange and the NASDAQ Stock Market simultaneously instituted standards requiring listed companies to have a majority of independent directors. This regulation did force firms to add independent directors, as fewer than $80 \%$ of firms had a majority of independent directors in $2003 .{ }^{3}$ Furthermore, SOX and the listing standards impose new responsibilities on firms' directors, such as regular meetings of the independent directors, approval of director nominations by independent directors, and approval of CEO compensation by independent directors. As a consequence of these policies, boards began including more independent directors, ${ }^{4}$ and, arguably, the independent directors became more engaged in the firm's governance processes.

While the explicit objective of the SOX and exchange regulations is increasing and improving board effectiveness through greater independence, it is possible that the firm's entire corporate governance environment changes, regardless of how corporate governance is measured. There are many plausible proxies for corporate governance, but there is no agreed-upon "best" measure. As such, it is possible these other measures have also been impacted by the new regulations. GIM (2003) create a governance index (G-Index) using 24 antitakeover provisions. They show that firms with strong shareholder rights outperform firms with weak shareholder rights by $8.50 \%$ per year during the 1990 s. They further show that firms with strong shareholder rights have higher firm value, higher profits, and higher sales growth. Core, Guay, and Rusticus (2006) extend this work and show that firms with weaker governance as measured by G-Index have lower operating performance (and that this is anticipated by the market). BCF (2009) modify the $G$-Index using only 6 of the 24 provisions to create an entrenchment index (E-Index), and find that firms with higher E-Index scores (associated with weaker governance) have lower firm valuation.

Beyond looking at indices that are comprised of various corporate governance components, a substantial body of work considers individual firm characteristics

\footnotetext{
${ }^{2}$ See Securities Exchange Act Release No. 47137 (Jan. 8, 2003), 68 FR 2637 (Jan. 17, 2003), or http://www.sec.gov/rules/sro/34-48745.htm.

${ }^{3}$ Firms could also meet the independence requirement by removing employee and affiliated directors from the board and reducing the size of the board.

${ }^{4}$ As indicated in Table 1, the percentage of directors that are independent increased from $62 \%$ in 1998 to $72 \%$ in 2007.
} 
as measures of corporate governance. These studies focus on the relationship between a single firm governance characteristic and firm performance. The literature on board independence and firm performance is discussed above. Brickley, Coles, and Jarrell (1997) study the benefits and costs of having the CEO also serve as the board chair. BB (2008) and Bhagat and Tookes (2012) consider the stock ownership of directors.

Can a single board characteristic be as effective a measure of corporate governance as indices that include dozens of corporate charter and board characteristics? $?^{5}$ While, ultimately, this is an empirical question, on both economic and econometric grounds it is possible. Bhagat, Bolton, and Romano (2008) argue that since boards have the power to make (or at least ratify) all important company decisions, it is plausible that board members with appropriate stock ownership will have the incentive to provide effective monitoring and oversight of these important corporate decisions. Also, simple measures such as board independence and director ownership can be a good proxy for overall good governance on econometric grounds: The measurement error associated with a simple variable such as board independence can be much less than the total measurement error in measuring a multitude of board processes, compensation structures, and charter provisions. Furthermore, construction of a governance index requires proper weighting of these board characteristics, antitakeover provisions, and compensation variables; if the weights in the index are not the same as the (unobservable) weights used by informed market participants in assessing the governance and performance relationship, then incorrect inferences would be made.

This paper is closest in spirit to BB (2008); however, we extend that work in 3 ways: First, BB consider governance-performance relationships only during the pre-SOX period of 1998-2002; we consider both pre-SOX (1998-2001) and postSOX (2003-2007) periods. Given the scope of SOX and that it was the 1st such significant corporate governance-related regulation in decades, it is important to consider the extent to which governance-performance relationships changed subsequent to the passage of SOX. For example, board independence is negatively correlated with performance pre-SOX, but positively correlated with performance post-SOX. Second, this study documents that firms that are not compliant with SOX regarding audit committee independence have significantly higher abnormal returns upon becoming compliant than do noncompliant firms that stay noncompliant; BB do not consider any market responses to changes in board structure. Finally, BB consider governance-performance relationships during 1998-2002 and propose a new governance measure (namely, dollar ownership of board directors). This study corroborates the statistical and economic significance of their governance measure with out-of-sample data.

\footnotetext{
${ }^{5}$ For example, Brown and Caylor's (2006) Gov-Score index includes 51 factors, while commercial providers such as RiskMetrics Group (formerly Institutional Shareholder Services), The Corporate Library, and Glass Lewis \& Company offer proprietary governance indices using, sometimes, several hundred governance characteristics.
} 


\section{Data Description and Model Specification}

\section{A. Data}

Our primary source of corporate governance data is the RiskMetrics directors and governance databases (formerly the Investor Responsibility Research Center (IRRC)). In addition, we use the Compustat Industrial Annual database for financial statement information, the Center for Research in Security Prices (CRSP) database for stock market data, and the Compustat Executive Compensation (ExecuComp) database for CEO ownership and turnover information. The Securities and Exchange Commission's (SEC) EDGAR database of SEC filings is also used to obtain specific information from proxy statements.

The RiskMetrics databases track governance and director information for approximately 1,500 large U.S. companies from 1990 to 2007. The governance database provides corporate antitakeover provisions on these companies, plus the G-Index score used in GIM (2003). This database provides updates for 1990, 1993, 1995, 1998, 2000, 2002, 2004, and 2007. The director database provides detailed director information annually from 1996 to 2007. However, the director ownership data are not tracked consistently until 1998, so our primary sample is for 1998-2007. The ExecuComp database provides compensation and ownership data on approximately 1,500 large U.S. firms annually from 1992 to 2007. There is considerable overlap across these sources: The final merged sample has 1,0001,400 firms per year. The final sample is an unbalanced panel with 10 years of data from 1998 to 2007 and a total of over 13,000 firm-year observations.

\section{B. Governance Variables}

This study considers the following 5 measures of corporate governance: ${ }^{6}$

Independence. Board independence is measured as the percentage of directors who are unaffiliated with the sample firm. This includes directors who are not employees of the firm and directors who do not have any identifiable relationship with the sample firm.

DirectorOwn. Director ownership is measured as the natural log of the dollar value of common stock owned by the median director. We focus on the dollar value rather than percentage of ownership because it serves as a more direct measure of director incentives. Consistent with the political economy literature, we focus on the median directors because they have the ability to cast the deciding vote on board issues (see Shleifer and Murphy (2004) and Milavonic (2004)).

CEO-Duality. CEO-Chair duality is an indicator variable taking the value of 1 if the CEO of the sample firm is also the board chair, and 0 otherwise.

\footnotetext{
${ }^{6}$ In supplementary tests, we consider 2 other measures of corporate governance. BusyBoards is the percentage of directors who serve on more than 3 corporate boards; our results are consistent with that of Fich and Shivdasani (2006). IndepInsider is the number of the sample firm's executives on the board who hold at least 1 additional outside directorship; our results are supportive of Masulis and Mobbs (2011).
} 
G-Index. From GIM (2003), the G-Index is the compilation of antitakeover provisions in the firm's bylaws. The index is comprised of 24 corporate charter provisions, with a possible index value ranging from 0 to 24 . Consistent with GIM, higher index values represent weaker corporate governance, while lower index values represent stronger corporate governance.

E-Index. From BCF (2009), the E-Index is a subset of the G-Index. It includes only 6 of the 24 corporate charter provisions believed consistent with entrenching management, thus taking a value of $0-6 .^{7}$ Again, higher index values represent weaker corporate governance.

\section{Performance Variables}

Consistent with Barber and Lyon (1996) and Core, Guay, and Rusticus (2006), we consider return on assets (ROA) as our primary measure of firm operating performance. In supplementary tests, we also use stock return (Return) and Tobin's $\mathrm{Q}(Q)$ as alternative measures of firm performance. Industry-adjusted performance is obtained by subtracting the average performance of the sample firm's 4-digit Standard Industrial Classification code from the sample firm's performance measure.

\section{Other Endogenous and Control Variables}

In addition to governance and performance, ownership and capital structure are also presumed to be endogenously determined. We consider CEOOwn\% as the percentage of stock owned by the CEO. Leverage is the capital structure measure, calculated as the long-term debt-to-assets ratio.

Regarding the control variables, prior literature (e.g., Core, Holthausen, and Larcker (1999), Gillan et al. (2003), and Core et al. (2006)) suggests that industry performance, return volatility, growth opportunities, and firm size are important determinants of firm performance. Yermack (1996) documents a relation between board size and performance. Demsetz (1983) suggests that small firms are more likely to be closely held, suggesting a different governance structure than large firms. Theoretical work on board independence (Hermalin and Weisbach (1998), Raheja (2005), Adams and Ferreira (2007), and Harris and Raviv (2008)) suggests that more independent boards are not necessarily value-enhancing; rather, there is an optimal level of board independence depending on the information cost that outside directors incur in becoming effective monitors. We consider the information cost (InfoCost) variables as developed in Krishnaswami and Subramanian (1999) as a determinant of board independence; specifically, we consider the standard deviation of monthly stock returns and the standard deviation of analyst forecasts.

FirmSize is the natural log of assets for the firm. $R \& D A d v E x p$ is the ratio of research and development plus advertising expenses to assets; if the data are

\footnotetext{
${ }^{7}$ The 6 provisions are staggered boards, limits to shareholder bylaw amendments, supermajority requirements for mergers, supermajority requirements for charter amendments, poison pills, and golden parachutes.
} 
missing, they are presumed to be zero. MktBook is the ratio of market to book value of equity. BoardSize is the number of directors on the board.

We adopt an IV approach to dealing with the potential endogeneity among governance, performance, ownership, and capital structure. We identify the following primary IV used in the 1st-stage fitted regressions. We utilize 3 instruments for the governance variables: Dir\%Own is the average percentage of common stock owned by all directors (this is different from DirectorOwn, which is the natural log of the dollar value of common stock owned by the median director). We use this variable as an instrument for all 5 governance variables. Dir\%CEOs is the percentage of directors who are CEOs; this variable is used as an instrument for Independence, DirectorOwn, and CEO-Duality. Hallock (1997) and Westphal and Khanna (2003) emphasize the role of networks among CEOs that serve on boards and the adverse impact on the governance of such firms. Dir\%15Ten is the percentage of directors who have served on the board for at least 15 years; this variable is used as an instrument for G-Index and E-Index. TreasStock is the ratio of treasury stock to assets, which we use as the primary instrument for performance (as in Palia (2001)). CEOTenAge is the ratio of CEO tenure to CEO age; this variable is used as the instrument for ownership. A CEO who has had 5 years of tenure at age 65 is likely to be of different quality and have a different equity ownership than a CEO that has had 5 years of tenure at age 50 . These CEOs likely have different incentive, reputation, and career concerns. Gibbons and Murphy (1992) provide evidence on this. Therefore, we use the ratio of CEO tenure to CEO age as a measure of CEO quality, which will serve as an instrument for CEO ownership. ZScore is the modified Altman's (1968) Z-Score; this variable is used as the instrument for leverage. ${ }^{8,9}$

\section{E. Model Specification}

The main relationship analyzed in this study is the effect that corporate governance has on firm performance. We note above the potential endogeneity between governance and performance. Bhagat and Jefferis (2002) highlight the reasons for focusing on the interrelationships between performance, governance, ownership, and capital structure. Therefore, we specify the following 4-equation system of equations allowing for these interdependencies:

\footnotetext{
${ }^{8}$ Our choice of the instrument variables is motivated by the extant literature. However, it is difficult for us to argue that the instruments are uncorrelated with the regression error terms. A vast body of theoretical and empirical literature has focused on the interrelationships between performance, governance, ownership, and capital structure; see Bhagat and Jefferis (2002). In light of the above interrelationships, and the model we are trying to estimate (equations (1a), (1b), (1c), and (1d) as noted), we think it is close to impossible to propose instruments that are in theory uncorrelated with the error terms. From an econometric perspective, validity of instruments is a matter of degree, not kind; see Berkowitz, Caner, and Fang (2008) and Chao and Swanson (2005). Ashbaugh-Skaife, Collins, and LaFond (2006) make a similar point in their study of the effects of corporate governance on firms' credit ratings. We implement a battery of tests checking for the validity and strength of our instruments, and specification of the system of equations; please see Section IV and the Internet Appendix (www.jfqa.org).

${ }^{9}$ We consider alternative instruments for leverage such as Graham's (1996) marginal tax rate; ZScore is more appropriate based on our diagnostic tests.
} 
(1a)

$$
\begin{aligned}
& \text { Performance }_{i, t}=\text { Governance }_{i, t}+\text { Ownership }_{i, t}+\text { Leverage }_{i, t} \\
& + \text { IndustryPerformance }_{i, t}+\text { FirmSize }_{i, t} \\
& +R \& D A d v \operatorname{Exp}_{i, t}+\text { BoardSize }_{i, t} \\
& + \text { InfoCost }_{i, t}+\text { TreasStock }_{i, t}+\varepsilon a_{i, t} \text {, }
\end{aligned}
$$

$$
\begin{aligned}
\text { Ownership }_{i, t}= & \text { Performance }_{i, t}+\text { Governance }_{i, t}+\text { Leverage }_{i, t} \\
& + \text { FirmSize }_{i, t}+\text { R\&DAdvExp } \\
i, t & + \text { BoardSize }_{i, t} \\
& + \text { InfoCost }_{i, t}+\text { CEOTenAge }_{i, t}+\varepsilon c_{i, t}, \\
\text { Leverage }_{i, t}= & \text { Performance }_{i, t}+\text { Governance }_{i, t}+\text { Ownership }_{i, t} \\
& + \text { IndustryLeverage }_{i, t}+\text { FirmSize }_{i, t}+\text { R\&DAdvExp }_{i, t} \\
& + \text { MktBook }_{i, t}+\text { BoardSize }_{i, t}+\text { InfoCost }_{i, t} \\
& + \text { ZScore }_{i, t}+\varepsilon d_{i, t} .
\end{aligned}
$$

The primary focus of this study is on equation (1a), and specifically on the coefficient on Governance in that equation. This relationship is studied for different time periods and for different subsamples.

In using IV estimation, 2 questions need to be addressed: Are the instruments valid, and is IV estimation necessary? An instrument is "weak" if the correlation between the instruments and the endogenous variable is small. Nelson and Startz (1990) and Bound, Jaeger, and Baker (1995) were among the first to discuss how IV estimation can perform poorly if the instruments are weak. Nelson and Startz show that the true distribution of the IV estimator may look nothing like the asymptotic distribution. Bound et al. focus on 2 related problems. First, if the instruments and the endogenous variables are weakly correlated, then even a weak correlation between the instruments and the error in the original structural equation (which should be 0) can lead to large inconsistencies in the IV estimates; this is known as the "bias" issue related to weak instruments. Second, finite sample results can differ substantially from asymptotic theory. Specifically, IV estimates are generally biased in the same direction as ordinary least squares (OLS) estimates, with the magnitude of this bias increasing as the $R^{2}$ of the 1 st-stage regression between the instruments and the endogenous variable approaches 0 ; this is known as the "size" issue related to weak instruments.

More recently, Stock and Yogo (2004) formalize the definitions and provide tests to determine if instruments are weak. They introduce 2 alternative definitions of weak instruments. First, a set of instruments is weak if the bias of the IV estimator, relative to the bias of the OLS estimator, exceeds a certain limit $b$. Second, the set of instruments is weak if the conventional $\alpha$-level Wald test based on IV statistics has a size that could exceed a certain threshold $r$. These 2 definitions correspond to the "bias" and "size" problems mentioned earlier.

Consistent with the recommendations of Chenhall and Moers (2007), we use the Stock and Yogo (2004) test for weak instruments and the Hahn and 
Hausman (2002) test for the validity of the instruments. We also use the DurbinWu-Hausman specification test based on Hausman (1978) to test for differences between the OLS and 2-stage least squares (2SLS) results and to determine which estimation method is more appropriate for statistical inference. ${ }^{10}$

\section{Corporate Governance and Firm Performance}

\section{A. Descriptive Statistics}

Table 1 presents the descriptive statistics for the main governance, performance, and other variables for the entire sample and for the pre- and post-2002 subsamples. In general, the summary statistics for the entire sample period are similar to prior literature. The average board has 9.3 directors, $67 \%$ of whom are outsiders. The average $G$-Index is 9.2, and the average E-Index is 2.2. The median director owns about $\$ 887,000$ worth of company stock, and the CEO is also the board chair in about $60 \%$ of the firms.

TABLE 1

\section{Descriptive Statistics}

Table 1 presents the mean, median, and standard deviation for the primary governance, performance, and other variables. The statistics are presented for 3 time periods: the full sample, 1998-2007; and the 2 subsamples, 1998-2001 and 20032007. The variables are as defined in the text. The number of observations refers to observations with Independence only; the other governance variables may have slightly more or fewer observations, depending on availability.

\begin{tabular}{|c|c|c|c|c|c|c|c|c|c|}
\hline & \multicolumn{3}{|c|}{$1998-2007(n=13,135)$} & \multicolumn{3}{|c|}{ 1998-2001 $(n=5,230)$} & \multicolumn{3}{|c|}{ 2003-2007 $(n=6,683)$} \\
\hline & Mean & Median & Std Dev & Mean & Median & Std Dev & Mean & Median & Std Dev \\
\hline Governance Variables & & & & & & & & & \\
\hline Independence & $67.03 \%$ & $70.00 \%$ & $17.28 \%$ & $61.56 \%$ & $63.64 \%$ & $19.90 \%$ & $71.95 \%$ & $75.00 \%$ & $14.55 \%$ \\
\hline DirectorOwn & 13.696 & 13.739 & 1.584 & 13.580 & 13.486 & 1.890 & 13.898 & 13.943 & 1.348 \\
\hline CEO-Duality & $59.55 \%$ & $100.00 \%$ & $43.05 \%$ & $59.46 \%$ & $100.00 \%$ & $40.75 \%$ & $58.28 \%$ & $100.00 \%$ & $42.26 \%$ \\
\hline G-Index & 9.176 & 9.000 & 2.663 & 8.887 & 9.000 & 2.789 & 9.356 & 9.000 & 2.579 \\
\hline E-Index & 2.210 & 2.000 & 1.298 & 2.029 & 2.000 & 1.325 & 2.332 & 2.000 & 1.269 \\
\hline Performance Variables & & & & & & & & & \\
\hline$R O A$ & $12.50 \%$ & $12.38 \%$ & $8.11 \%$ & $12.63 \%$ & $12.85 \%$ & $8.49 \%$ & $13.02 \%$ & $12.28 \%$ & $7.75 \%$ \\
\hline Return & $13.20 \%$ & $7.28 \%$ & $38.00 \%$ & $13.81 \%$ & $1.95 \%$ & $42.72 \%$ & $17.82 \%$ & $13.72 \%$ & $32.87 \%$ \\
\hline Q & 1.999 & 1.522 & 1.018 & 2.200 & 1.472 & 1.119 & 1.957 & 1.594 & 0.961 \\
\hline Other Variables & & & & & & & & & \\
\hline CEOOWn\% & $1.78 \%$ & $0.00 \%$ & $3.86 \%$ & $3.53 \%$ & $0.00 \%$ & $4.63 \%$ & $1.32 \%$ & $0.00 \%$ & $3.02 \%$ \\
\hline Leverage & $18.56 \%$ & $16.14 \%$ & $13.45 \%$ & $20.15 \%$ & $17.65 \%$ & $13.84 \%$ & $17.62 \%$ & $15.19 \%$ & $12.97 \%$ \\
\hline FirmSize & 7.671 & 7.508 & 1.676 & 7.480 & 7.294 & 1.659 & 7.876 & 7.699 & 1.674 \\
\hline$R \& D A d v E x p$ & $3.90 \%$ & $0.97 \%$ & $4.63 \%$ & $4.06 \%$ & $0.52 \%$ & $4.63 \%$ & $3.62 \%$ & $1.16 \%$ & $4.62 \%$ \\
\hline BoardSize & 9.251 & 9.000 & 2.873 & 9.265 & 9.000 & 3.340 & 9.381 & 9.000 & 2.529 \\
\hline InfoCost & $11.20 \%$ & $9.32 \%$ & $5.48 \%$ & $14.49 \%$ & $12.41 \%$ & $6.05 \%$ & $8.27 \%$ & $7.38 \%$ & $3.89 \%$ \\
\hline TreasStock & $5.71 \%$ & $0.28 \%$ & $10.57 \%$ & $6.07 \%$ & $0.28 \%$ & $9.78 \%$ & $8.01 \%$ & $0.31 \%$ & $10.65 \%$ \\
\hline Dir\%Own & $0.41 \%$ & $0.05 \%$ & $2.24 \%$ & $0.40 \%$ & $0.05 \%$ & $5.36 \%$ & $0.14 \%$ & $0.51 \%$ & $0.45 \%$ \\
\hline Dir\%CEOs & $24.22 \%$ & $22.22 \%$ & $13.87 \%$ & $26.53 \%$ & $25.00 \%$ & $16.11 \%$ & $21.36 \%$ & $20.00 \%$ & $11.92 \%$ \\
\hline Dir\%15Ten & $15.95 \%$ & $11.11 \%$ & $19.59 \%$ & $16.37 \%$ & $10.00 \%$ & $20.98 \%$ & $14.26 \%$ & $11.11 \%$ & $16.01 \%$ \\
\hline CEOTenAge & 0.135 & 0.095 & 0.119 & 0.153 & 0.108 & 0.122 & 0.129 & 0.093 & 0.109 \\
\hline MktBook & 2.684 & 2.240 & 1.708 & 3.397 & 2.200 & 1.912 & 2.763 & 2.303 & 1.560 \\
\hline ZScore & 2.037 & 1.986 & 0.950 & 2.028 & 1.985 & 0.971 & 2.061 & 1.997 & 0.940 \\
\hline
\end{tabular}

\footnotetext{
${ }^{10}$ In addition to 2 SLS, we also consider 3 SLS, which allows for cross-correlation in the errors of the equations in the system. There is qualitatively very little difference between the 2SLS and 3SLS results, so we only report the 2 SLS results.
} 
Some notable differences are seen when we compare the pre- and post2002 subsamples. We note that post-2002 boards have become more independent, directors own more stock, boards have become more entrenched (with G-Index increasing from 8.9 to 9.4 and E-Index increasing from 2.0 to 2.3), but slightly fewer CEOs are serving as board chair. Fewer directors are active CEOs. The size of the board has remained relatively constant, but Independence has increased from $61.6 \%$ before 2002 to $72.0 \%$ after 2002. Median director ownership has significantly increased from about $\$ 790,000$ before 2002 to about $\$ 1,100,000$ after 2002.

Table 2 presents the correlation coefficients for select governance and other variables. For the most part, the governance variables are not highly correlated, with the exception of G-Index and E-Index. Independence and G-Index are moderately highly correlated, consistent with Gillan et al. (2007).

TABLE 2

\section{Correlation Coefficients}

Table 2 presents the correlation coefficients for the primary governance variables and other select variables. Pearson correlation coefficients are below the diagonal; Spearman rank correlation coefficients are above the diagonal. Panel A presents the coefficients for 1998-2001, and Panel B presents the coefficients for 2003-2007.
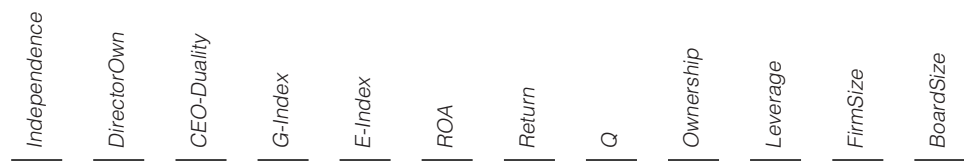

Panel A. Correlation Coefficients: 1998-2001

Independence
DirectorOwn
CEO-Duality
G-Index
E-Index
ROA
Return
Q
Ownership

$\begin{array}{rrr}- & -0.29 & \\ -0.23 & - & -0.0 \\ 0.05 & -0.03 & \\ 0.27 & -0.04 & 0.1 \\ 0.28 & -0.10 & 0.0 \\ 0.02 & 0.07 & 0.0 \\ -0.02 & 0.15 & -0.0 \\ -0.06 & 0.31 & -0.0 \\ -0.19 & 0.10 & 0.1 \\ 0.00 & -0.08 & 0.0 \\ 0.16 & 0.08 & 0.1 \\ 0.14 & -0.04 & 0.1\end{array}$

\section{$0.06 \quad 0.29$}

$0.28-0.04$

0.13

0.07
0.74

$0.10-$

$0.07 \quad 0.74$

$\begin{array}{ll}0.01 & 0.02\end{array}$

$-0.01-0.04$

$-0.02$

$\begin{array}{ll}0.02 & -0.11 \\ 0.10 & -0.14\end{array}$

$0.03 \quad 0.06$

$0.15 \quad 0.17$

$\begin{array}{ll}0.14 & 0.24\end{array}$

$-0.03$

$-0.03$

$-0.13$

$-0.15$

0.06
0.05

Panel B. Correlation Coefficients: 2003-2007

\begin{tabular}{lrrrrrrrrrrrr} 
Independence & - & -0.18 & 0.10 & 0.18 & 0.17 & -0.04 & -0.03 & -0.04 & -0.10 & 0.09 & 0.17 & 0.12 \\
DirectorOwn & -0.17 & - & -0.04 & -0.09 & -0.07 & 0.21 & 0.12 & 0.40 & 0.05 & -0.13 & 0.13 & -0.03 \\
CEO-Duality & 0.09 & -0.05 & - & 0.11 & 0.07 & -0.02 & 0.06 & -0.06 & 0.06 & 0.06 & 0.14 & 0.05 \\
G-Index & 0.18 & -0.07 & 0.11 & - & 0.71 & -0.02 & 0.05 & -0.10 & -0.10 & 0.12 & 0.16 & 0.25 \\
E-Index & 0.18 & -0.07 & 0.07 & 0.70 & - & -0.07 & 0.04 & -0.10 & -0.05 & 0.09 & 0.02 & 0.12 \\
ROA & -0.04 & 0.17 & -0.02 & -0.02 & -0.07 & - & 0.11 & 0.61 & -0.02 & -0.08 & -0.18 & -0.12 \\
Return & -0.05 & 0.08 & 0.03 & 0.02 & 0.02 & 0.08 & - & 0.21 & 0.01 & 0.00 & 0.02 & 0.00 \\
Q & -0.04 & 0.31 & -0.05 & -0.09 & -0.11 & 0.47 & 0.21 & - & 0.03 & -0.34 & -0.25 & -0.21 \\
Ownership & -0.15 & 0.01 & 0.07 & -0.14 & -0.14 & 0.04 & -0.02 & 0.04 & - & -0.10 & -0.29 & -0.24 \\
Leverage & 0.06 & -0.09 & 0.03 & 0.08 & 0.06 & -0.05 & -0.03 & -0.26 & -0.08 & - & 0.30 & 0.22 \\
FirmSize & 0.16 & 0.10 & 0.14 & 0.12 & 0.00 & -0.13 & -0.04 & -0.22 & -0.15 & 0.20 & - & 0.61 \\
BoardSize & 0.09 & 0.01 & 0.05 & 0.21 & 0.10 & -0.11 & -0.05 & -0.19 & -0.14 & 0.11 & 0.61 & - \\
\hline
\end{tabular}

\section{B. Governance and Performance, Pre- and Post-2002 Periods}

The year 2002 was seminal in terms of corporate governance regulation, specifically with respect to board independence. We use 2002 as the break-point 
for our 2 subperiods, since SOX was enacted in 2002; for this reason, we exclude 2002 from our analysis. ${ }^{11}$

We find the most interesting result when we consider the relationship between Independence and ROA during the pre- and post-2002 periods. Consistent with the extant literature, we find Independence is negatively related to $R O A$ during the 1998-2001 period (see Panel B of Table 3). ${ }^{12}$ However, during the 2003-2007 period, we find that Independence is positively and significantly related to ROA (see Panel D). Boards have become more independent, and now this independence is positively correlated with better operating performance.

A 2nd interesting result in Table 3 is that the relationship between $R O A$ and $G$-Index is negative and significant in the pre-2002 period (Panel B), but positive and significant during the post-2002 period (Panel D). The other 3 governance variables (DirectorOwn, CEO-Duality, and E-Index) all have similar signs and significance pre- and post-2002. Director ownership is positively related to operating performance, whereas $C E O$-Duality and E-Index are negatively related. (Recall that lower values of the E-Index and CEO-Duality are associated with better governance.)

Table 3 also summarizes the relationship between various governance measures and stock market-based measures of performance, Return and $Q$. Consistent with the efficient market hypothesis, we do not find any consistent significant relation between any measure of governance (including those proposed by GIM (2003) and BCF (2009)) and stock market-based measures of performance. This evidence is consistent with a growing body of evidence that does not find a consistent and significant relationship between governance measures proposed by GIM and BCF and stock market-based measures of performance (e.g., see Johnson, Moorman, and Sorescu (2009), Core et al. (2006), Lehn, Patro, and Zhao (2007), and Cremers and Nair (2005)).

Table 4 summarizes the relationship between various governance measures and future firm performance. In general, these results are consistent with those discussed above. One exception to this is the relationship between $R O A$ in the next 2 years and E-Index, which reverses from negative prior to 2002 to positive after 2002.

We next try to better characterize and understand the surprising significant positive relation between board independence and operating performance for the period 2003-2007. Using the sample of 13,135 firm-year observations, we determine the year-to-year change in the number of independent directors for each firm-year. An increase in the number of independent directors from the previous year is observed for only about $1 / 3$ of these observations. In Panel A of Table 5, we observe a significant positive relation between board independence and contemporaneous operating performance for the period 2003-2007 for those observations where there is an increase in the number of independent directors from the

\footnotetext{
${ }^{11}$ The results are robust to excluding both 2002 and 2003 from the analysis. We choose to include 2003, because many firms were compliant with SOX by 2003.

${ }^{12}$ In Panels A and C of Table 3, we report OLS and 2SLS results for completeness. However, the Hausman (1978) test indicates that the 2SLS estimates are more appropriate for inference; see Appendix A in the Internet Appendix.
} 
previous year; this is in contrast to the negative relation for the period 1998-2001. In Panel B, we consider observations where there is no increase in the number of independent directors from the previous year: We do not observe a significant relation between board independence and contemporaneous operating performance

TABLE 3

Governance and Performance, Equation (1a)

Table 3 presents the results from estimating equation (1a), the performance equation. Five different specifications are presented with 5 different governance variables: Independence, board independence; DirectorOwn, the dollar value of the median director's stock ownership; CEO-Duality, whether or not the CEO is also the board chair; G-Index, the GIM (2003) governance index; and E-Index, the BCF (2009) entrenchment index. Here, ROA, return on assets in the current period, is used as the measure of performance. All other variables are as defined in the text. Panel A presents the results using ordinary least squares (OLS) for the 1998-2001 period; Panel B presents the results using 2-stage least squares (2SLS) for the 1998-2001 period: Panel C presents the results using OLS for the 2003-2007 period; and Panel D presents the results using 2SLS for the 2003-2007 period. An intercept and year and industry dummy variables are included but not presented. Standard errors are clustered by firm. Coefficients are presented with $p$-values below in parentheses. ***, ${ }^{* *}$, and ${ }^{*}$ indicate significance at the $1 \%, 5 \%$, and $10 \%$ levels, respectively.

Dependent Variable: Return on Assets $\left(R O A_{t}\right)$

$\underline{\underline{\text { Independence } t}} \quad \underline{\text { DirectorOwnt }_{t}} \quad \underline{\text { CEO-Duality }} \quad \quad \underline{\text { G-Index }} \quad \underline{E \text {-Index }}$

Panel A. OLS Estimation: 1998-2001

\begin{tabular}{|c|c|c|c|c|c|}
\hline Governance $_{t}$ & $\begin{array}{l}-0.027^{\star \star \star} \\
(0.01)\end{array}$ & $\begin{array}{l}0.015^{\star \star *} \\
(0.00)\end{array}$ & $\begin{array}{c}-0.003 \\
(0.57)\end{array}$ & $\begin{array}{c}-0.001 \\
(0.54)\end{array}$ & $\begin{array}{l}-0.006^{\star \star \star} \\
(0.00)\end{array}$ \\
\hline Ownershipt & $\begin{array}{c}-0.001 \\
(0.80)\end{array}$ & $\begin{array}{c}-0.001 \\
(0.38)\end{array}$ & $\begin{array}{c}0.000 \\
(0.59)\end{array}$ & $\begin{array}{c}-0.001 \\
(0.93)\end{array}$ & $\begin{array}{c}-0.001 \\
(0.51)\end{array}$ \\
\hline Leverage $_{t}$ & $\begin{array}{l}-0.123^{\star \star * *} \\
(0.00)\end{array}$ & $\begin{array}{l}-0.105^{\star \star \star} \\
(0.00)\end{array}$ & $\begin{array}{l}-0.122^{\star \star \star} \\
(0.00)\end{array}$ & $\begin{array}{c}-0.133^{\star \star \star} \\
(0.00)\end{array}$ & $\begin{array}{l}-0.131^{\text {*ᄎ }} \\
(0.00)\end{array}$ \\
\hline IndustryPerformance $t$ & $\begin{array}{l}0.575^{\star \star \star} \\
(0.00)\end{array}$ & $\begin{array}{l}0.565^{\star \star \star *} \\
(0.00)\end{array}$ & $\begin{array}{l}0.576^{\star \star \star} \\
(0.00)\end{array}$ & $\begin{array}{l}0.590^{\star \star \star} \\
(0.00)\end{array}$ & $\begin{array}{l}0.588^{\star \star *} \\
(0.00)\end{array}$ \\
\hline FirmSize $t$ & $\begin{array}{c}-0.003 \\
(0.11)\end{array}$ & 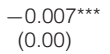 & $\begin{array}{c}-0.003 \\
(0.11)\end{array}$ & $\begin{array}{c}-0.002 \\
(0.15)\end{array}$ & $\begin{array}{c}-0.003^{\star} \\
(0.07)\end{array}$ \\
\hline$R \& D A d v E x p_{t}$ & $\begin{array}{l}-0.895^{\star * *} \\
(0.00)\end{array}$ & $\begin{array}{l}-0.940^{\text {*** }} \\
(0.00)\end{array}$ & $\begin{array}{l}-0.897^{* * *} \\
(0.00)\end{array}$ & $\begin{array}{c}-0.890^{\star \star \star} \\
(0.00)\end{array}$ & $\begin{array}{l}-0.898^{\star \star \star} \\
(0.00)\end{array}$ \\
\hline BoardSize $_{t}$ & $\begin{array}{l}-0.003^{\star \star *} \\
(0.00)\end{array}$ & $\begin{array}{c}-0.002^{\star} \\
(0.05)\end{array}$ & $\begin{array}{l}-0.003^{\star \star \star} \\
(0.00)\end{array}$ & $\begin{array}{l}-0.003^{\star \star \star} \\
(0.00)\end{array}$ & $\begin{array}{l}-0.003^{\star \star \star} \\
(0.00)\end{array}$ \\
\hline InfoCost $t_{t}$ & $\begin{array}{l}-0.076^{\star \star \star} \\
(0.00)\end{array}$ & $\begin{array}{l}-0.094^{\text {*** }} \\
(0.00)\end{array}$ & $\begin{array}{l}-0.074^{\star \star \star} \\
(0.00)\end{array}$ & $\begin{array}{c}-0.053^{\star} \\
(0.06)\end{array}$ & $\begin{array}{l}-0.059^{\star \star} \\
(0.04)\end{array}$ \\
\hline TreasStockt & $\begin{array}{l}0.263^{\star \star \star *} \\
(0.00)\end{array}$ & $\begin{array}{l}0.266^{* * *} \\
(0.00)\end{array}$ & $\begin{array}{l}0.263^{\star \star \star} \\
(0.00)\end{array}$ & $\begin{array}{l}0.261^{* \star \star} \\
(0.00)\end{array}$ & $\begin{array}{l}0.261^{\star * *} \\
(0.00)\end{array}$ \\
\hline No. of obs. & 5,156 & 4,665 & 5,156 & 4,566 & 4,566 \\
\hline \multicolumn{6}{|c|}{ Panel B. 2SLS Estimation: 1998-2001 } \\
\hline Governance $_{t}$ & $\begin{array}{l}-0.739^{* \star *} \\
(0.00)\end{array}$ & $\begin{array}{l}0.028^{* *} \\
(0.02)\end{array}$ & $\begin{array}{l}-0.167^{\star \star \star} \\
(0.00)\end{array}$ & $\begin{array}{l}-0.097^{\star \star *} \\
(0.00)\end{array}$ & $\begin{array}{l}-0.196^{\star \star \star} \\
(0.00)\end{array}$ \\
\hline Ownershipt & $\begin{array}{l}-0.014^{\star \star *} \\
(0.00)\end{array}$ & $\begin{array}{l}-0.008^{\text {*** }} \\
(0.01)\end{array}$ & $\begin{array}{c}-0.001^{\star} \\
(0.10)\end{array}$ & $\begin{array}{l}-0.016^{\star \star \star} \\
(0.00)\end{array}$ & $\begin{array}{l}-0.014^{\star \star \star} \\
(0.00)\end{array}$ \\
\hline Leverage $_{t}$ & $\begin{array}{l}-0.205^{\star \star \star} \\
(0.00)\end{array}$ & $\begin{array}{l}-0.200^{\star \star \star} \\
(0.00)\end{array}$ & $\begin{array}{l}-0.202^{\star \star *} \\
(0.00)\end{array}$ & $\begin{array}{c}-0.213^{\star \star \star} \\
(0.00)\end{array}$ & $\begin{array}{l}-0.274^{\star \star \star} \\
(0.00)\end{array}$ \\
\hline IndustryPerformance $t$ & $\begin{array}{l}0.714^{\star \star *} \\
(0.00)\end{array}$ & $\begin{array}{l}0.694^{\star \star *} \\
(0.00)\end{array}$ & $\begin{array}{l}0.694^{\star \star \star} \\
(0.00)\end{array}$ & $\begin{array}{l}0.791^{\star \star \star} \\
(0.00)\end{array}$ & $\begin{array}{l}0.708^{\star \star \star} \\
(0.00)\end{array}$ \\
\hline FirmSize $t$ & $\begin{array}{l}0.015^{\star \star \star} \\
(0.00)\end{array}$ & $\begin{array}{c}0.006 \\
(0.33)\end{array}$ & $\begin{array}{l}0.002^{\star \star \star} \\
(0.00)\end{array}$ & $\begin{array}{c}0.006 \\
(0.30)\end{array}$ & $\begin{array}{c}-0.003 \\
(0.67)\end{array}$ \\
\hline$R \& D A d v E x p_{t}$ & $\begin{array}{l}-0.689^{* * *} \\
(0.00)\end{array}$ & $\begin{array}{l}-0.753^{\text {*** }} \\
(0.00)\end{array}$ & $\begin{array}{l}-0.658^{* * *} \\
(0.00)\end{array}$ & $\begin{array}{c}-0.910^{\star \star \star} \\
(0.00)\end{array}$ & $\begin{array}{l}-0.795^{\text {** }} \\
(0.00)\end{array}$ \\
\hline BoardSize $_{t}$ & $\begin{array}{l}-0.008^{* * *} \\
(0.00)\end{array}$ & $\begin{array}{l}-0.006^{\star \star} \\
(0.01)\end{array}$ & $\begin{array}{l}-0.005^{\star \star} \\
(0.04)\end{array}$ & $\begin{array}{c}0.002 \\
(0.68)\end{array}$ & $\begin{array}{c}-0.004 \\
(0.20)\end{array}$ \\
\hline InfoCost & $\begin{array}{l}-0.226^{\star \star \star} \\
(0.00)\end{array}$ & $\begin{array}{l}-0.198^{\text {*** }} \\
(0.01)\end{array}$ & $\begin{array}{c}-0.190^{\star \star} \\
(0.01)\end{array}$ & $\begin{array}{c}-0.390^{\star \star \star} \\
(0.00)\end{array}$ & $\begin{array}{l}-0.251^{\star \star} \\
(0.01)\end{array}$ \\
\hline TreasStockt & $\begin{array}{l}0.367^{\star \star \star} \\
(0.00)\end{array}$ & $\begin{array}{l}0.364^{* * *} \\
(0.00)\end{array}$ & $\begin{array}{l}0.389^{\star \star \star} \\
(0.00)\end{array}$ & $\begin{array}{l}0.368^{* \star \star} \\
(0.00)\end{array}$ & $\begin{array}{l}0.329^{\star \star \star} \\
(0.00)\end{array}$ \\
\hline No. of obs. & 5,156 & 4,665 & 5,156 & 4,566 & 4,566 \\
\hline
\end{tabular}




\begin{tabular}{|c|c|c|c|c|c|}
\hline \multirow{2}{*}{\multicolumn{6}{|c|}{$\begin{array}{l}\text { TABLE } 3 \text { (continued) } \\
\text { Governance and Performance, Equation (1a) }\end{array}$}} \\
\hline \multicolumn{4}{|c|}{ Governance and Performance, Equation (1a) } & & \\
\hline & \multicolumn{5}{|c|}{ Dependent Variable: Return on Assets $\left(R O A_{t}\right)$} \\
\hline & Independence $t$ & $\underline{\text { DirectorOwn }}$ & CEO-Dualityt & G-Indext & E-Indext \\
\hline \multicolumn{6}{|c|}{ Panel C. OLS Estimation: 2003-2007 } \\
\hline Governance $t$ & $\begin{array}{c}0.014 \\
(0.14)\end{array}$ & $\begin{array}{l}0.015^{\star \star \star} \\
(0.00)\end{array}$ & $\begin{array}{r}-0.001 \\
(0.65)\end{array}$ & $\begin{array}{c}-0.001^{*} \\
(0.07)\end{array}$ & $\begin{array}{c}-0.004 \\
(0.00)\end{array}$ \\
\hline Ownershipt & $\begin{array}{l}0.000^{* *} \\
(0.05)\end{array}$ & $\begin{array}{l}0.000^{\star} \\
(0.07)\end{array}$ & $\begin{array}{l}0.000^{\star \star} \\
(0.02)\end{array}$ & $\begin{array}{l}0.000^{\star} \\
(0.08)\end{array}$ & $\begin{array}{c}0.000 \\
(0.17)\end{array}$ \\
\hline Leverage $_{t}$ & $\begin{array}{c}-0.042^{\star \star \star} \\
(0.00)\end{array}$ & $\begin{array}{c}-0.021^{\star \star \star} \\
(0.01)\end{array}$ & $\begin{array}{l}-0.042^{\star \star \star} \\
(0.00)\end{array}$ & $\begin{array}{c}-0.042^{* * *} \\
(0.00)\end{array}$ & $\begin{array}{c}-0.041^{\star \star *} \\
(0.00)\end{array}$ \\
\hline IndustryPerformance $t_{t}$ & $\begin{array}{l}0.478^{\star \star \star} \\
(0.00)\end{array}$ & $\begin{array}{l}0.461^{\star \star \star} \\
(0.00)\end{array}$ & $\begin{array}{l}0.477^{\star \star \star} \\
(0.00)\end{array}$ & $\begin{array}{l}0.470^{\star \star \star} \\
(0.00)\end{array}$ & $\begin{array}{l}0.468^{* * \star} \\
(0.00)\end{array}$ \\
\hline FirmSize $_{t}$ & $\begin{array}{l}-0.003^{\star \star \star} \\
(0.00)\end{array}$ & $\begin{array}{l}-0.006^{\star \star \star} \\
(0.00)\end{array}$ & $\begin{array}{l}-0.003^{* \star \star} \\
(0.00)\end{array}$ & 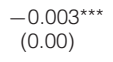 & $\begin{array}{l}-0.004^{\star \star \star} \\
(0.00)\end{array}$ \\
\hline$R \& D A d v E_{x p}$ & $\begin{array}{c}-0.202^{\star \star \star} \\
(0.00)\end{array}$ & $\begin{array}{c}-0.242^{\star \star \star} \\
(0.00)\end{array}$ & $\begin{array}{l}-0.204^{* \star \star} \\
(0.00)\end{array}$ & $\begin{array}{l}-0.199^{* * *} \\
(0.00)\end{array}$ & $\begin{array}{c}-0.203^{\star \star \star} \\
(0.00)\end{array}$ \\
\hline BoardSizet & $\begin{array}{c}-0.003^{\star \star \star} \\
(0.00)\end{array}$ & $\begin{array}{l}-0.002^{\star \star \star} \\
(0.01)\end{array}$ & 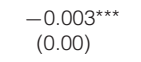 & $\begin{array}{l}-0.003^{\text {*** }} \\
(0.00)\end{array}$ & $\begin{array}{c}-0.002^{\star \star \star} \\
(0.00)\end{array}$ \\
\hline InfoCost $t_{t}$ & $\begin{array}{c}-0.456^{\star \star \star} \\
(0.00)\end{array}$ & $\begin{array}{l}-0.414^{\star * *} \\
(0.00)\end{array}$ & $\begin{array}{c}-0.454^{\star \star *} \\
(0.00)\end{array}$ & $\begin{array}{c}-0.460^{* * \star} \\
(0.00)\end{array}$ & $\begin{array}{l}-0.464^{\text {*** }} \\
(0.00)\end{array}$ \\
\hline TreasStockt & $\begin{array}{l}0.147^{\star \star \star} \\
(0.00)\end{array}$ & $\begin{array}{l}0.147^{\star \star \star} \\
(0.00)\end{array}$ & $\begin{array}{l}0.147^{\star \star \star} \\
(0.00)\end{array}$ & $\begin{array}{l}0.147^{\star \star \star} \\
(0.00)\end{array}$ & $\begin{array}{l}0.147^{\text {***}} \\
(0.00)\end{array}$ \\
\hline No. of obs. & 6,515 & 6,377 & 6,515 & 7,665 & 7,665 \\
\hline \multicolumn{6}{|c|}{ Panel D. 2SLS Estimation: 2003-2007 } \\
\hline Governance $_{t}$ & $\begin{array}{l}0.178^{\star \star} \\
(0.01)\end{array}$ & $\begin{array}{l}0.006^{\star *} \\
(0.03)\end{array}$ & $\begin{array}{c}-0.029^{* *} \\
(0.04)\end{array}$ & $\begin{array}{c}0.014 \\
(0.16)\end{array}$ & $\begin{array}{c}-0.493^{*} \\
(0.05)\end{array}$ \\
\hline Ownership $t$ & $\begin{array}{l}0.002^{*} \\
(0.05)\end{array}$ & $\begin{array}{c}0.000 \\
(0.16)\end{array}$ & $\begin{array}{r}0.001 \\
(0.15)\end{array}$ & $\begin{array}{r}0.001 \\
(0.18)\end{array}$ & $\begin{array}{l}0.018^{*} \\
(0.06)\end{array}$ \\
\hline Leverage $_{t}$ & $\begin{array}{c}-0.671^{\star \star \star} \\
(0.00)\end{array}$ & $\begin{array}{c}-0.656^{\star \star \star} \\
(0.00)\end{array}$ & $\begin{array}{c}-0.649^{* * *} \\
(0.00)\end{array}$ & $\begin{array}{l}-0.673^{* * *} \\
(0.00)\end{array}$ & $\begin{array}{c}-0.030^{*} \\
(0.09)\end{array}$ \\
\hline IndustryPerformance $t$ & $\begin{array}{l}0.537^{\star \star \star} \\
(0.00)\end{array}$ & $\begin{array}{l}0.537^{\star \star \star} \\
(0.00)\end{array}$ & $\begin{array}{l}0.537^{\star \star \star} \\
(0.00)\end{array}$ & $\begin{array}{l}0.544^{\star \star \star} \\
(0.00)\end{array}$ & $\begin{array}{l}0.501^{*} \\
(0.07)\end{array}$ \\
\hline FirmSize $_{t}$ & $\begin{array}{c}-0.005^{\star \star \star} \\
(0.00)\end{array}$ & $\begin{array}{c}-0.007^{\star \star \star} \\
(0.00)\end{array}$ & $\begin{array}{c}-0.008^{* * *} \\
(0.00)\end{array}$ & $\begin{array}{c}-0.008^{\star * \star} \\
(0.00)\end{array}$ & $\begin{array}{c}-0.072^{*} \\
(0.08)\end{array}$ \\
\hline$R \& D A d v E x p_{t}$ & $\begin{array}{l}-0.481^{\star \star \star} \\
(0.00)\end{array}$ & $\begin{array}{l}-0.453^{\star * *} \\
(0.00)\end{array}$ & $\begin{array}{l}-0.456^{* * *} \\
(0.00)\end{array}$ & $\begin{array}{l}-0.396^{* * *} \\
(0.00)\end{array}$ & $\begin{array}{l}-0.500^{\star * \star} \\
(0.01)\end{array}$ \\
\hline BoardSize $_{t}$ & $\begin{array}{c}-0.003 \\
(0.28)\end{array}$ & $\begin{array}{r}-0.001 \\
(0.27)\end{array}$ & $\begin{array}{r}-0.001 \\
(0.37)\end{array}$ & $\begin{array}{c}-0.003^{\star} \\
(0.09)\end{array}$ & $\begin{array}{c}-0.031^{*} \\
(0.07)\end{array}$ \\
\hline InfoCost $t_{t}$ & $\begin{array}{c}-0.266^{\star \star \star} \\
(0.00)\end{array}$ & $\begin{array}{l}-0.305^{\star \star \star} \\
(0.00)\end{array}$ & $\begin{array}{c}-0.313^{* * *} \\
(0.00)\end{array}$ & $\begin{array}{l}-0.212^{\star * \star} \\
(0.01)\end{array}$ & $\begin{array}{c}-0.288^{* *} \\
(0.03)\end{array}$ \\
\hline TreasStockt & $\begin{array}{l}0.156^{\star \star \star} \\
(0.00)\end{array}$ & $\begin{array}{l}0.163^{\star \star \star} \\
(0.00)\end{array}$ & $\begin{array}{l}0.165^{\star \star \star} \\
(0.00)\end{array}$ & $\begin{array}{l}0.156^{\star \star \star} \\
(0.00)\end{array}$ & $\begin{array}{l}0.150^{\text {***}} \\
(0.01)\end{array}$ \\
\hline No. of obs. & 6,515 & 6,377 & 6,515 & 7,665 & 7,665 \\
\hline
\end{tabular}

for the period 2003-2007. Hence, the positive relation between board independence and operating performance for the period 2003-2007 appears to be driven by those companies that increase their number of independent directors from the previous year. This is consistent with and supportive of the event-study results of Chhaochharia and Grinstein (2007), who find that firms that were less compliant with the rules imposed by SOX and the exchanges earned positive abnormal returns on the announcement of the rules.

We document above that director ownership is positively correlated with operating performance. It is possible that the positive relation between board independence and operating performance for the period 2003-2007 might be due to 
TABLE 4

Governance and Performance (Equation (1a)) by Subperiod

Table 4 presents the results from estimating equation (1a), the performance equation, across 2 different time periods: 1998-2001 and 2003-2007. Only the coefficient and p-value associated with the Governance variable in equation (1a) is presented. Five different specifications are presented with 5 different governance variables: Independence, board independence; DirectorOwn, the dollar value of the median director's stock ownership; CEO-Duality, whether or not the CEO is also the board chair; G-Index, the GIM (2003) governance index; and E-Index, the BCF (2009) entrenchment index. Only the coefficient on the Governance variable in equation (1a) is presented. Three different measures of performance are estimated: ROA, return on assets; Return, stock return; and $Q$, Tobin's Q. Performance is measured in 3 different time periods: $t, t+1, t+2$. All other variables are as defined in the text. Ordinary least squares (OLS) and 2-stage least squares (2SLS) results are both presented. An intercept and year and industry dummy variables are included but not presented. Standard errors are clustered by firm. Coefficients are presented with $p$-values below in parentheses. ${ }^{\star \star \star},{ }^{\star \star}$, and ${ }^{*}$ indicate significance at the $1 \%, 5 \%$, and $10 \%$ levels, respectively.

\begin{tabular}{|c|c|c|c|c|c|c|c|c|c|c|c|}
\hline \multicolumn{12}{|c|}{ Dependent Variable } \\
\hline \multicolumn{4}{|c|}{$\begin{array}{c}\text { Contemporaneous } \\
\text { Performance }\end{array}$} & \multicolumn{4}{|c|}{$\begin{array}{l}\text { Next Year's } \\
\text { Performance }\end{array}$} & \multicolumn{4}{|c|}{$\begin{array}{l}\text { Next } 2 \text { Years' } \\
\text { Performance }\end{array}$} \\
\hline & & & & & & & & & & & \\
\hline OLS & 2SLS & OLS & 2SLS & OLS & 2SLS & OLS & 2SLS & OLS & 2SLS & OLS & 2SLS \\
\hline
\end{tabular}

Panel A. Independencet

\begin{tabular}{|c|c|c|c|c|c|c|c|c|c|c|c|c|}
\hline$R O A$ & $\begin{array}{l}-0.027^{\star \star \star} \\
(0.01)\end{array}$ & $\begin{array}{l}-0.739^{\star \star \star \star} \\
(0.00)\end{array}$ & $\begin{array}{c}0.014 \\
(0.14)\end{array}$ & $\begin{array}{l}0.178^{\star \star} \\
(0.01)\end{array}$ & $\begin{array}{l}-0.043^{\text {}} \\
(0.00)\end{array}$ & $\begin{array}{l}-0.401^{\text {*** }} \\
(0.00)\end{array}$ & $\begin{array}{l}0.019^{\star \star} \\
(0.03)\end{array}$ & $\begin{array}{c}0.116 \\
(0.10)\end{array}$ & $\begin{array}{l}-0.020^{* * *} \\
(0.00)\end{array}$ & $\begin{array}{l}-0.081^{\star} \\
(0.06)\end{array}$ & $\begin{array}{l}0.016^{\star \star \star} \\
(0.00)\end{array}$ & $\begin{array}{c}0.013 \\
(0.10)\end{array}$ \\
\hline Return & $\begin{array}{c}-0.051 \\
(0.33)\end{array}$ & $\begin{array}{c}-0.352 \\
(0.27)\end{array}$ & $\begin{array}{c}0.021 \\
(0.56)\end{array}$ & $\begin{array}{c}-0.180 \\
(0.39)\end{array}$ & $\begin{array}{c}-0.033 \\
(0.61)\end{array}$ & $\begin{array}{c}-0.594 \\
(0.13)\end{array}$ & $\begin{array}{c}0.017 \\
(0.60)\end{array}$ & $\begin{array}{c}-0.129 \\
(0.47)\end{array}$ & $\begin{array}{c}-0.037 \\
(0.21)\end{array}$ & $\begin{array}{l}-0.357^{* *} \\
(0.05)\end{array}$ & $\begin{array}{c}0.008 \\
(0.59)\end{array}$ & $\begin{array}{c}-0.047 \\
(0.61)\end{array}$ \\
\hline$Q$ & $\begin{array}{l}-0.537^{\star \star \star} \\
(0.00)\end{array}$ & $\begin{array}{c}-0.641 \\
(0.55)\end{array}$ & $\begin{array}{c}-0.250^{\star} \\
(0.06)\end{array}$ & $\begin{array}{c}0.351 \\
(0.19)\end{array}$ & $\begin{array}{l}-0.457^{\star \star} \\
(0.01)\end{array}$ & $\begin{array}{c}1.319 \\
(0.32)\end{array}$ & $\begin{array}{c}-0.269 \\
(0.13)\end{array}$ & $\begin{array}{c}0.833 \\
(0.23)\end{array}$ & $\begin{array}{l}-0.317^{*} \\
(0.07)\end{array}$ & $\begin{array}{c}-2.210^{*} \\
(0.05)\end{array}$ & $\begin{array}{c}-0.393 \\
(0.33)\end{array}$ & $\begin{array}{c}0.613 \\
(0.14)\end{array}$ \\
\hline $\begin{array}{l}\text { No. of } \\
\text { obs. }\end{array}$ & 5,156 & 5,156 & 6,515 & 6,515 & 4,537 & 4,537 & 5,738 & 5,738 & 3,354 & 3,354 & 4,558 & 4,558 \\
\hline \multicolumn{13}{|c|}{ Panel B. DirectorOwnt } \\
\hline$R O A$ & $\begin{array}{l}0.015^{\star \star \star} \\
(0.00)\end{array}$ & $\begin{array}{l}0.028^{* \star} \\
(0.02)\end{array}$ & $\begin{array}{l}0.015^{\star * *} \\
(0.00)\end{array}$ & $\begin{array}{l}0.006^{\star \star} \\
(0.03)\end{array}$ & $\begin{array}{l}0.008^{\star \star \star} \\
(0.00)\end{array}$ & $\begin{array}{l}0.034^{* \star *} \\
(0.00)\end{array}$ & $\begin{array}{l}0.012^{\star \star \star} \\
(0.00)\end{array}$ & $\begin{array}{c}0.004 \\
(0.13)\end{array}$ & $\begin{array}{l}0.004^{* * *} \\
(0.00)\end{array}$ & $\begin{array}{l}0.010^{\star \star \star} \\
(0.00)\end{array}$ & $\begin{array}{l}0.003^{\star \star \star} \\
(0.00)\end{array}$ & $\begin{array}{c}0.003^{*} \\
(0.07)\end{array}$ \\
\hline Return & 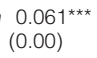 & $\begin{array}{l}0.046^{\star \star} \\
(0.03)\end{array}$ & $\begin{array}{l}0.025^{\star \star *} \\
(0.00)\end{array}$ & $\begin{array}{l}0.021^{*} \\
(0.10)\end{array}$ & $\begin{array}{c}0.006 \\
(0.41)\end{array}$ & $\begin{array}{l}0.073^{* * *} \\
(0.00)\end{array}$ & $\begin{array}{c}0.018 \\
(0.28)\end{array}$ & $\begin{array}{c}0.012 \\
(0.28)\end{array}$ & $\begin{array}{c}0.003 \\
(0.35)\end{array}$ & $\begin{array}{l}0.029^{*} \\
(0.09)\end{array}$ & $\begin{array}{c}0.009 \\
(0.11)\end{array}$ & $\begin{array}{c}0.003 \\
(0.26)\end{array}$ \\
\hline$Q$ & $\begin{array}{l}0.417^{\star \star \star} \\
(0.00)\end{array}$ & $\begin{array}{l}0.345^{\star \star \star} \\
(0.00)\end{array}$ & $\begin{array}{l}0.286^{\star \star \star} \\
(0.00)\end{array}$ & $\begin{array}{l}-0.033 \\
(0.54)\end{array}$ & $\begin{array}{l}0.308^{\star \star \star} \\
(0.00)\end{array}$ & $\begin{array}{l}0.452^{\star \star \star} \\
(0.00)\end{array}$ & $\begin{array}{l}0.234^{\star \star \star} \\
(0.00)\end{array}$ & $\begin{array}{c}0.015 \\
(0.44)\end{array}$ & $\begin{array}{l}0.174^{\star \star *} \\
(0.00)\end{array}$ & $\begin{array}{l}0.250 \\
(0.18)\end{array}$ & $\begin{array}{c}0.142 \\
(0.12)\end{array}$ & $\begin{array}{c}0.142 \\
(0.18)\end{array}$ \\
\hline $\begin{array}{l}\text { No. of } \\
\text { obs. }\end{array}$ & 4,665 & 4,665 & 6,377 & 6,377 & 4,537 & 4,537 & 5,738 & 5,738 & 2,976 & 2,976 & 4,300 & 4,300 \\
\hline \multicolumn{13}{|c|}{ Panel C. CEO-Duality } \\
\hline$R O A$ & $\begin{array}{c}-0.003 \\
(0.57)\end{array}$ & 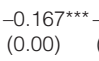 & $\begin{array}{c}-0.001 \\
(0.65)\end{array}$ & $\begin{array}{l}-0.029^{\star \star} \\
(0.04)\end{array}$ & $\begin{array}{c}-0.003 \\
(0.43)\end{array}$ & $\begin{array}{l}-0.094^{* * *} \\
(0.00)\end{array}$ & $\begin{array}{c}-0.003 \\
(0.41)\end{array}$ & $\begin{array}{c}-0.024 \\
(0.12)\end{array}$ & $\begin{array}{c}-0.003 \\
(0.30)\end{array}$ & $\begin{array}{l}-0.023^{\star *} \\
(0.02)\end{array}$ & $\begin{array}{l}-0.003^{\star} \\
(0.06)\end{array}$ & $\begin{array}{c}-0.005 \\
(0.37)\end{array}$ \\
\hline Return - & $\begin{array}{c}-0.034 \\
(0.18)\end{array}$ & $\begin{array}{c}-0.088 \\
(0.22)\end{array}$ & $\begin{array}{c}-0.009 \\
(0.46)\end{array}$ & $\begin{array}{c}-0.019 \\
(0.61)\end{array}$ & $\begin{array}{c}-0.024 \\
(0.45)\end{array}$ & $\begin{array}{l}-0.193^{\star \star} \\
(0.03)\end{array}$ & $\begin{array}{c}-0.007 \\
(0.58)\end{array}$ & $\begin{array}{c}-0.027 \\
(0.50)\end{array}$ & $\begin{array}{c}-0.021 \\
(0.15)\end{array}$ & $\begin{array}{l}-0.950^{* *} \\
(0.02)\end{array}$ & $\begin{array}{c}-0.007 \\
(0.28)\end{array}$ & $\begin{array}{c}-0.012 \\
(0.56)\end{array}$ \\
\hline$Q$ & $\begin{array}{c}-0.077 \\
(0.28)\end{array}$ & $\begin{array}{c}-0.243 \\
(0.27)\end{array}$ & $\begin{array}{c}-0.062 \\
(0.18)\end{array}$ & $\begin{array}{c}0.028 \\
(0.86)\end{array}$ & $\begin{array}{c}-0.121 \\
(0.17)\end{array}$ & $\begin{array}{c}-0.297 \\
(0.28)\end{array}$ & $\begin{array}{c}-0.082^{*} \\
(0.09)\end{array}$ & $\begin{array}{c}0.091 \\
(0.59)\end{array}$ & $\begin{array}{c}0.058 \\
(0.50)\end{array}$ & $\begin{array}{c}-0.199 \\
(0.45)\end{array}$ & $\begin{array}{c}-0.048 \\
(0.50)\end{array}$ & $\begin{array}{c}-0.409 \\
(0.21)\end{array}$ \\
\hline $\begin{array}{l}\text { No. of } \\
\text { obs. }\end{array}$ & 5,156 & 5,156 & 6,515 & 6,515 & 4,537 & 4,537 & 5,738 & 5,738 & 3,354 & 3,354 & 4,558 & 4,558 \\
\hline \multicolumn{13}{|c|}{ Panel D. G-Indext } \\
\hline$R O A$ & $\begin{array}{c}-0.001 \\
(0.54)\end{array}$ & $\begin{array}{l}-0.097^{\star \star \star} \\
(0.00)\end{array}$ & $\begin{array}{l}-0.001^{*} \\
(0.07)\end{array}$ & $\begin{array}{c}0.014 \\
(0.16)\end{array}$ & $\begin{array}{l}0.002^{\star \star \star} \\
(0.00)\end{array}$ & $\begin{array}{l}-0.040^{* *} \\
(0.04)\end{array}$ & $\begin{array}{c}-0.007 \\
(0.15)\end{array}$ & $\begin{array}{l}0.035^{\text {}} \\
(0.00)\end{array}$ & $\begin{array}{l}-0.001^{* *} \\
(0.01)\end{array}$ & $\begin{array}{l}-0.019^{* *} \\
(0.03)\end{array}$ & $\begin{array}{c}-0.001 \\
(0.30)\end{array}$ & $\begin{array}{c}0.014 \\
(0.39)\end{array}$ \\
\hline Return - & $\begin{array}{c}-0.001 \\
(0.82)\end{array}$ & $\begin{array}{c}-0.049 \\
(0.28)\end{array}$ & $\begin{array}{c}0.003 \\
(0.11)\end{array}$ & $\begin{array}{c}-0.015 \\
(0.52)\end{array}$ & $\begin{array}{c}0.006 \\
(0.13)\end{array}$ & $\begin{array}{l}-0.106^{* *} \\
(0.05)\end{array}$ & $\begin{array}{l}-0.003^{*} \\
(0.06)\end{array}$ & $\begin{array}{c}-0.006 \\
(0.72)\end{array}$ & $\begin{array}{c}-0.003 \\
(0.23)\end{array}$ & $\begin{array}{l}-0.073^{*} \\
(0.06)\end{array}$ & $\begin{array}{c}0.001 \\
(0.25)\end{array}$ & $\begin{array}{c}0.007 \\
(0.53)\end{array}$ \\
\hline$Q$ & $\begin{array}{l}-0.047^{\star \star \star} \\
(0.00)\end{array}$ & $\begin{array}{l}-0.583^{\star \star \star} \\
(0.00)\end{array}$ & $\begin{array}{l}-0.027^{\star \star * *} \\
(0.00)\end{array}$ & $\begin{array}{c}0.138 \\
(0.18)\end{array}$ & $\begin{array}{l}-0.031^{\star \star \star} \\
(0.00)\end{array}$ & $\begin{array}{l}-0.248^{\star \star} \\
(0.05)\end{array}$ & $\begin{array}{l}-0.020^{\star \star \star} \\
(0.00)\end{array}$ & $\begin{array}{l}0.144^{*} \\
(0.08)\end{array}$ & $\begin{array}{c}-0.016 \\
(0.19)\end{array}$ & $\begin{array}{c}-0.150 \\
(0.39)\end{array}$ & $\begin{array}{c}-0.011 \\
(0.40)\end{array}$ & $\begin{array}{c}0.018 \\
(0.90)\end{array}$ \\
\hline $\begin{array}{l}\text { No. of } \\
\text { obs. }\end{array}$ & 4,566 & 4,566 & 7,665 & 7,665 & 3,758 & 3,758 & 6,733 & 6,733 & 2,909 & 2,909 & 5,479 & 5,479 \\
\hline
\end{tabular}


TABLE 4 (continued)

\section{Governance and Performance (Equation (1a)) by Subperiod}

\begin{tabular}{|c|c|c|c|c|c|c|c|c|c|c|c|c|}
\hline & \multicolumn{12}{|c|}{ Dependent Variable } \\
\hline & \multicolumn{4}{|c|}{$\begin{array}{c}\text { Contemporaneous } \\
\text { Performance }\end{array}$} & \multicolumn{4}{|c|}{$\begin{array}{l}\text { Next Year's } \\
\text { Performance }\end{array}$} & \multicolumn{4}{|c|}{$\begin{array}{l}\text { Next } 2 \text { Years' } \\
\text { Performance }\end{array}$} \\
\hline & \multicolumn{2}{|c|}{$\begin{array}{c}1998- \\
2001 \\
\end{array}$} & \multicolumn{2}{|c|}{$\begin{array}{l}2003- \\
2007\end{array}$} & \multicolumn{2}{|c|}{$\begin{array}{l}1998- \\
2001 \\
\end{array}$} & \multicolumn{2}{|c|}{$\begin{array}{c}2003- \\
2007 \\
\end{array}$} & \multicolumn{2}{|c|}{$\begin{array}{c}1998- \\
2001 \\
\end{array}$} & \multicolumn{2}{|c|}{$\begin{array}{c}2003- \\
2007 \\
\end{array}$} \\
\hline & OLS & 2SLS & OLS & 2SLS & OLS & 2SLS & OLS & $2 S L S$ & OLS & 2SLS & OLS & $2 S L S$ \\
\hline \multicolumn{13}{|c|}{ Panel E. E-Index } \\
\hline$R O A$ & $\begin{array}{l}-0.006^{\star \star \star} \\
(0.00)\end{array}$ & $\begin{array}{l}-0.196^{\star \star \star} \\
(0.00)\end{array}$ & $\begin{array}{l}-0.004^{* * *} \\
(0.00)\end{array}$ & $\begin{array}{l}-0.493^{*} \\
(0.05)\end{array}$ & $\begin{array}{l}-0.004^{\star * *} \\
(0.00)\end{array}$ & $\begin{array}{l}-0.247^{\star \star \star} \\
(0.01)\end{array}$ & $\begin{array}{l}-0.004^{\star \star \star} \\
(0.00)\end{array}$ & $\begin{array}{c}-0.126 \\
(0.17)\end{array}$ & $\begin{array}{l}-0.003^{\star \star \star} \\
(0.00)\end{array}$ & $\begin{array}{l}-0.047^{\star \star} \\
(0.03)\end{array}$ & $\begin{array}{l}-0.001^{* *} \\
(0.02)\end{array}$ & $\begin{array}{l}0.067^{*} \\
(0.01)\end{array}$ \\
\hline Return & $\begin{array}{c}0.000 \\
(0.99)\end{array}$ & $\begin{array}{c}-0.118 \\
(0.28)\end{array}$ & $\begin{array}{r}0.007 \\
(0.10)\end{array}$ & $\begin{array}{l}-0.156 \\
(0.24)\end{array}$ & $\begin{array}{r}0.007 \\
(0.48)\end{array}$ & $\begin{array}{l}-0.488^{\star \star} \\
(0.04)\end{array}$ & $\begin{array}{r}0.007 \\
(0.30)\end{array}$ & $\begin{array}{c}-0.189 \\
(0.26)\end{array}$ & $\begin{array}{c}0.003 \\
(0.54)\end{array}$ & $\begin{array}{l}-0.176^{*} \\
(0.05)\end{array}$ & $\begin{array}{l}0.004^{\star} \\
(0.05)\end{array}$ & $\begin{array}{l}-0.020 \\
(0.68)\end{array}$ \\
\hline$Q$ & $\begin{array}{l}-0.135^{\star \star \star} \\
(0.00)\end{array}$ & $\begin{array}{l}-0.202^{\star \star \star} \\
(0.00)\end{array}$ & $\begin{array}{l}-0.072^{* \star *} \\
(0.00)\end{array}$ & $\begin{array}{l}0.383 \\
(0.21)\end{array}$ & $\begin{array}{l}-0.149^{\star \star *} \\
(0.00)\end{array}$ & $\begin{array}{l}-2.428^{* * *} \\
(0.01)\end{array}$ & $\begin{array}{l}-0.070^{\star \star \star *} \\
(0.00)\end{array}$ & $\begin{array}{c}0.977 \\
(0.17)\end{array}$ & $\begin{array}{l}-0.074^{\star \star \star} \\
(0.01)\end{array}$ & $\begin{array}{l}-0.953^{\star \star} \\
(0.05)\end{array}$ & $\begin{array}{c}-0.059 \\
(0.28)\end{array}$ & $\begin{array}{c}-0.395 \\
(0.12)\end{array}$ \\
\hline $\begin{array}{c}\text { No. of } \\
\text { obs. }\end{array}$ & 4,566 & 4,566 & 7,665 & 7,665 & 3,758 & 3,758 & 6,733 & 6,733 & 2,909 & 2,909 & 5,479 & 5,479 \\
\hline
\end{tabular}

TABLE 5

\section{Governance and Performance (Equation (1a)) by Change in Independent Directors}

Table 5 presents the results from estimating equation (1a), the performance equation, across the 2 different time periods, 1998-2001 and 2003-2007, for 2 unique subsamples: those firms that increased their number of independent directors and those that did not. Five different specifications are presented with 5 different governance variables: Independence, board independence; DirectorOwn, the dollar value of the median director's stock ownership; CEO-Duality, whether or not the CEO is also the board chair; G-Index, the GIM (2003) governance index; and E-Index, the BCF (2009) entrenchment index. Only the coefficient on the Governance variable in equation (1a) is presented. Return on assets, $R O A$, is the measure of performance. Panel A gives the results for the subsample of firms that increased the number of independent directors on its board; Panel B gives the results for the subsample of firms that did not increase the number of independent directors on its board. All other variables are as defined in the text. Only 2-stage least squares (2SLS) results are presented. An intercept and year and industry dummy variables are included but not presented. Standard errors are clustered by firm Coefficients are presented with $p$-values below in parentheses. ${ }^{* \star *},{ }^{* *}$, and * indicate significance at the $1 \%, 5 \%$, and $10 \%$ levels, respectively.

Dependent Variable

\begin{tabular}{|c|c|c|c|c|c|}
\hline \multicolumn{2}{|c|}{$\begin{array}{c}\text { Contemporaneous } \\
\text { ROA }\end{array}$} & \multicolumn{2}{|c|}{$\begin{array}{c}\text { Next Year's } \\
\text { ROA }\end{array}$} & \multicolumn{2}{|c|}{$\begin{array}{c}\text { Next } 2 \text { Years' } \\
\text { ROA } \\
\end{array}$} \\
\hline $\begin{array}{l}1998- \\
2001\end{array}$ & $\begin{array}{l}2003- \\
2007\end{array}$ & $\begin{array}{l}1998- \\
2001\end{array}$ & $\begin{array}{c}2003- \\
2007\end{array}$ & $\begin{array}{l}1998- \\
2001\end{array}$ & $\begin{array}{c}2003- \\
2007\end{array}$ \\
\hline \multicolumn{6}{|c|}{ Iumber of Independent Directors } \\
\hline $\begin{array}{c}-0.412^{\star} \\
(0.10) \\
1,344\end{array}$ & $\begin{array}{l}0.509^{\star \star \star} \\
(0.00) \\
2,066\end{array}$ & $\begin{array}{c}-0.583^{\star * *} \\
(0.00) \\
1,187\end{array}$ & $\begin{array}{c}0.114^{\star} \\
(0.10) \\
1,982\end{array}$ & $\begin{array}{r}-0.052 \\
(0.29) \\
887\end{array}$ & $\begin{array}{c}0.177^{\text {** }} \\
(0.03) \\
1,588\end{array}$ \\
\hline $\begin{array}{c}0.018^{\star \star} \\
(0.03) \\
1,283\end{array}$ & $\begin{array}{c}0.001^{\star \star \star} \\
(0.01) \\
1,967\end{array}$ & $\begin{array}{c}0.017^{\star \star \star} \\
(0.00) \\
1,160\end{array}$ & $\begin{array}{l}0.009^{\star \star \star} \\
(0.00) \\
1,871\end{array}$ & $\begin{array}{r}0.011 \\
(0.12) \\
863\end{array}$ & $\begin{array}{c}0.007^{* *} \\
(0.02) \\
1,454\end{array}$ \\
\hline $\begin{array}{r}-0.087 \\
(0.18) \\
1,344\end{array}$ & $\begin{array}{c}-0.004 \\
(0.84) \\
2,066\end{array}$ & $\begin{array}{c}-0.092^{\star \star \star} \\
(0.01) \\
1,187\end{array}$ & $\begin{array}{c}0.000 \\
(0.98) \\
1,982\end{array}$ & $\begin{array}{r}-0.012 \\
(0.52) \\
887\end{array}$ & $\begin{array}{c}-0.075^{\star \star \star} \\
(0.00) \\
1,588\end{array}$ \\
\hline $\begin{array}{c}-0.053 \\
(0.13) \\
1,208\end{array}$ & $\begin{array}{c}0.040^{\star} \\
(0.08) \\
2,015\end{array}$ & $\begin{array}{c}0.010 \\
(0.27) \\
1,085\end{array}$ & $\begin{array}{c}-0.047^{\star \star \star} \\
(0.00) \\
1,958\end{array}$ & $\begin{array}{r}0.005 \\
(0.56) \\
793\end{array}$ & $\begin{array}{c}-0.033^{* * *} \\
(0.01) \\
1,621\end{array}$ \\
\hline $\begin{array}{c}-0.063 \\
(0.32) \\
1,208\end{array}$ & $\begin{array}{r}-0.567 \\
(0.27) \\
2,015\end{array}$ & $\begin{array}{c}-0.169^{* \star *} \\
(0.00) \\
1,085\end{array}$ & $\begin{array}{c}-0.004^{\star \star \star} \\
(0.00) \\
1,958\end{array}$ & $\begin{array}{r}-0.008 \\
(0.58) \\
793\end{array}$ & $\begin{array}{c}-0.071^{\star \star} \\
(0.03) \\
1,621\end{array}$ \\
\hline
\end{tabular}

(continued on next page) 


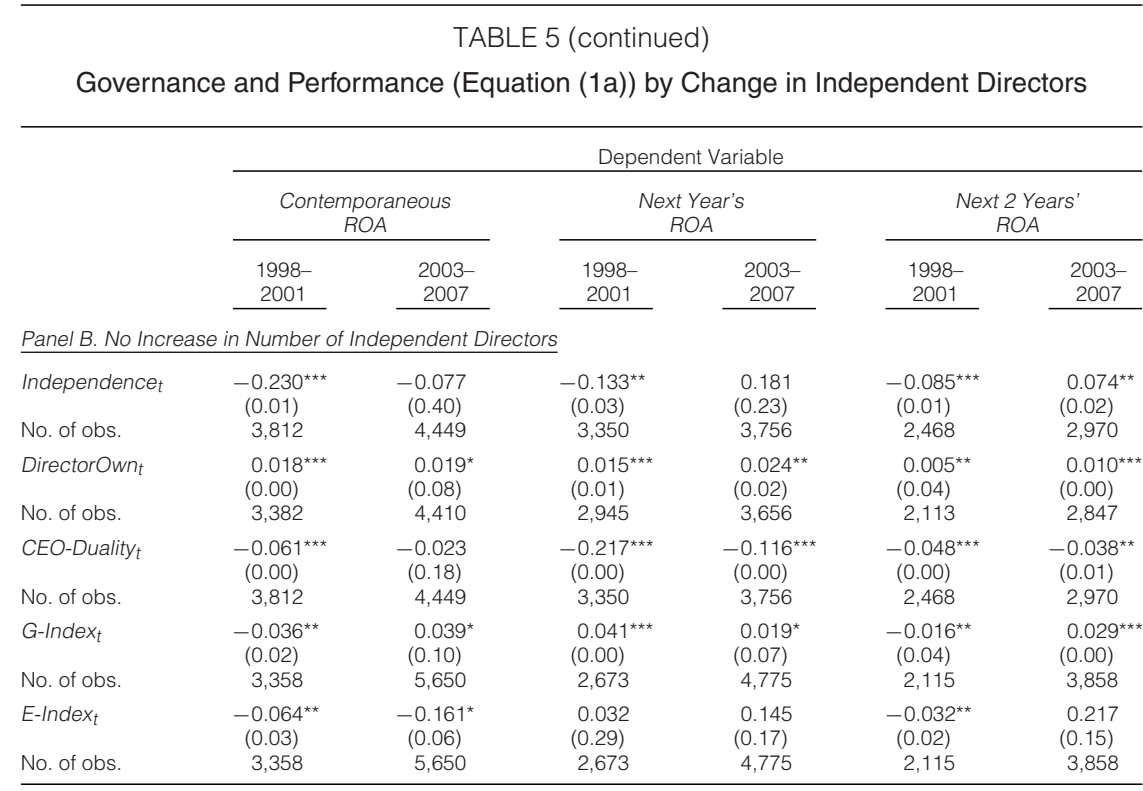

an increase in director ownership over the period 2003-2007. We examine this possibility in Table 6 by including both director ownership and board independence along with the other variables in equation (1a). This involves adding a 5 th equation to the system and using all 3 governance IV. Consistent with the evidence in Tables 3 and 4, we document a significant positive relation between board independence and contemporaneous operating performance for the period 2003-2007; this is in contrast to the negative relation for the period 1998-2001. Director ownership is positively associated with firm performance during both

TABLE 6

Two Endogenous Governance Variables

\begin{tabular}{|c|c|c|c|c|c|c|}
\hline & & & Depenc & Variable & & \\
\hline & Contemp & eous ROA & Next & $S R O A$ & Next 2 & S'ROA \\
\hline & 1998-2001 & 2003-2007 & $\underline{1998-2001}$ & 2003-2007 & 1998-2001 & 2003-2007 \\
\hline DirectorOwnt & $\begin{array}{l}0.010^{* *} \\
(0.03)\end{array}$ & $\begin{array}{l}0.199^{* *} \\
(0.03)\end{array}$ & $\begin{array}{l}0.009^{\star \star \star} \\
(0.00)\end{array}$ & $\begin{array}{c}0.012 \\
(0.17)\end{array}$ & $\begin{array}{l}0.004^{\star \star \star} \\
(0.00)\end{array}$ & $\begin{array}{l}0.002^{\star \star \star} \\
(0.00)\end{array}$ \\
\hline Independencet & $\begin{array}{c}-0.325^{\star *} \\
(0.03)\end{array}$ & $\begin{array}{l}0.480^{* *} \\
(0.04)\end{array}$ & $\begin{array}{c}-0.015 \\
(0.15)\end{array}$ & $\begin{array}{l}0.391^{\star \star} \\
(0.02)\end{array}$ & $\begin{array}{c}-0.006 \\
(0.37)\end{array}$ & $\begin{array}{l}0.009^{\star \star} \\
(0.02)\end{array}$ \\
\hline No. of obs. & 4,492 & 6,035 & 2,515 & 5,332 & 1,861 & 4,217 \\
\hline
\end{tabular}


the subsample periods. This indicates that the reversal of the relationship between board independence and operating performance after SOX is independent of the governance effects of director ownership.

\section{Robustness Checks}

We perform 11 robustness checks to increase our confidence in the performance-governance results noted in Tables 3 and 4. For example, we conduct the Stock and Yogo (2004) test to ensure that our instruments are strong. We also perform the Hansen (1982)-Sargan (1958) overidentification test and the Cragg-Donald (1993) test for model identification. We estimate the performancegovernance relationship using the fixed effects estimator including firm and year fixed effects, and clustered (Rogers (1993)) standard errors. We include marketto-book in our system of equations. We consider alternative measures of operating performance. Finally, following Duchin, Matsusaka, and Ozbas (2010), we construct an InfoCost index and evaluate its impact on the performance-governance relationship. Detailed results of these and other robustness checks are in the Internet Appendix. Briefly, the performance-governance results obtained after performing these robustness checks are entirely consistent with the performancegovernance results noted in Tables 3 and 4.

\section{Market Response to Firms' Announcement of Compliance}

The focus of this paper is on the impact of SOX on the performancegovernance relation. We find a negative and significant relationship between board independence and operating performance during 1998-2001, but a positive and significant relationship during 2003-2007. Also, we find that this result is driven by firms that increase their number of independent directors. Given that SOX attempts to increase the number and role of independent board members, the above evidence suggests a positive correlation between SOX's board independence requirements and company performance. However, correlation is not causation, as other economic events during 2003-2007 could lead to the above observed correlation (e.g., increased shareholder activism and corporate scandals in that period).

To get additional insight on the impact of SOX on the relation between board independence and company performance, we conduct an event study. We focus on the announcement by sample firms of the nomination of additional independent directors that would enable the firm to comply with SOX's board independence requirements for the audit committee. ${ }^{13}$ We use the filing of the firm's annual proxy statement as the event date. Table 7 summarizes the stock market's response to these announcements. When a company goes from being noncompliant to being compliant with SOX's board independence requirement, the market response

\footnotetext{
${ }^{13}$ Section III, subsection 301 of SOX required that all audit committee members of the board be independent; $69.9 \%$ of our sample firms were SOX compliant in 2002; $76.9 \%$ in 2003, $82.9 \%$ in 2004, $85.8 \%$ in $2005,84.6 \%$ in 2006 , and $96.8 \%$ in 2007 . In practice, firms become compliant by removing affiliated directors from the board, or when the nature of an affiliated relationship changes.
} 
TABLE 7

\section{Event-Study Results}

Table 7 presents the results from event studies performed on a sample of firms that were not compliant with Section 301 of SOX in year $t-1$. Section 301 requires that all members of a firm's audit committee be independent. Market-adjusted cumulative abnormal returns (CARs) are calculated for days $-1,0$, and +1 for years 2002 and 2003; day 0 is the proxy mailing date in year $t$. The value-weighted market is used as the market index. Two subsamples are considered: i) firms that were not compliant in year $t-1$ and became compliant in year $t$ in columns $1-5$; and, ii) firms that were not compliant in both year $t-1$ and year $t$ in columns $6-10$. Firm audit committees consisting only of independent directors are denoted as "Compliant." Firms whose audit committees do not consist only of independent directors are denoted as "Not Compliant." Panel A presents results from only firms that became SOX compliant and added independent directors to the board; Pane B presents the results from all firms that became SOX compliant. The nonparametric test is the Wilcoxon signed-rank test. The "Diff. in Means" in the last column tests for the difference in CARs between columns 1 and $6 .{ }^{* *}$ indicates results statistically different from Pre-SOX CAR at a $1 \%$ level.

\begin{tabular}{|c|c|c|c|c|c|c|c|c|c|c|}
\hline \multicolumn{5}{|c|}{ Compliant in Year $t$} & \multicolumn{5}{|c|}{ Not Compliant in Year $t$} & \multirow[b]{2}{*}{$\begin{array}{l}\text { Diff. in } \\
\text { Means, } \\
p \text {-Value }\end{array}$} \\
\hline CAR & $\begin{array}{c}z- \\
\text { Statistic }\end{array}$ & $\begin{array}{c}\text { Sample } \\
\text { Size }\end{array}$ & $\begin{array}{c}\text { Positive: } \\
\text { Negative } \\
\text { Returns }\end{array}$ & $\begin{array}{c}\text { Non- } \\
\text { parametric } \\
\text { Statistic }\end{array}$ & CAR & $\begin{array}{c}z- \\
\text { Statistic }\end{array}$ & $\begin{array}{l}\text { Sample } \\
\text { Size }\end{array}$ & $\begin{array}{l}\text { Positive: } \\
\text { Negative } \\
\text { Returns }\end{array}$ & $\begin{array}{c}\text { Non- } \\
\text { parametric } \\
\text { Statistic }\end{array}$ & \\
\hline 1 & 2 & 3 & 4 & 5 & 6 & 7 & 8 & 9 & 10 & $1-6$ \\
\hline
\end{tabular}

\begin{tabular}{|c|c|c|c|c|c|c|c|c|c|c|c|}
\hline Period & 1 & 2 & 3 & 4 & 5 & 6 & 7 & 8 & 9 & 10 & $1-6$ \\
\hline \multicolumn{12}{|c|}{ Panel A. Firms That Became Compliant and Added Independent Directors to the Audit Committee } \\
\hline All years & $0.48 \%$ & 2.586 & 826 & $445: 382$ & 3.029 & $0.26 \%$ & -0.078 & \multicolumn{2}{|c|}{$2,1401,049: 1,095$} & 2.425 & $<0.0001$ \\
\hline Pre-SOX & $0.57 \%$ & 1.303 & 293 & $184: 165$ & 1.811 & $0.38 \%$ & 1.032 & 1,239 & $728: 725$ & 2.997 & $<0.0001$ \\
\hline Post-SOX & $0.41 \%$ ** & 2.436 & 466 & $261: 217$ & 2.413 & $0.02 \%$ ** & 0.075 & 645 & $321: 370$ & -1.567 & $<0.0001$ \\
\hline 1998 & $-0.38 \%$ & -0.940 & 48 & $20: 28$ & -0.667 & $0.20 \%$ & -1.588 & 81 & $32: 49$ & -0.050 & $<0.0001$ \\
\hline 1999 & $0.15 \%$ & 0.478 & 72 & $36: 36$ & -0.438 & $-0.24 \%$ & -1.844 & 420 & $178: 242$ & -1.228 & $<0.0001$ \\
\hline 2000 & $0.54 \%$ & 1.067 & 78 & $41: 37$ & 1.222 & $1.33 \%$ & 4.073 & 383 & $218: 165$ & 5.546 & $<0.0001$ \\
\hline 2001 & $1.26 \%$ & 1.260 & 95 & $56: 39$ & 2.249 & $0.50 \%$ & 0.499 & 355 & $184: 171$ & 1.803 & $<0.0001$ \\
\hline 2002 & $0.97 \%$ & 1.801 & 67 & $36: 31$ & 1.151 & $-0.20 \%$ & -0.680 & 256 & $119: 137$ & -0.594 & $<0.0001$ \\
\hline 2003 & $0.86 \%$ & 1.939 & 99 & $59: 40$ & 1.231 & $-0.08 \%$ & -1.233 & 219 & $101: 118$ & -1.641 & $<0.0001$ \\
\hline 2004 & $0.27 \%$ & 1.685 & 93 & $54: 39$ & 0.921 & $0.26 \%$ & 0.298 & 150 & $67: 83$ & 0.698 & 0.1214 \\
\hline 2005 & $0.61 \%$ & 1.907 & 70 & $36: 34$ & 1.354 & $0.16 \%$ & 0.768 & 130 & $69: 61$ & 0.266 & $<0.0001$ \\
\hline 2006 & $0.49 \%$ & 0.771 & 38 & $20: 18$ & 0.854 & $-0.07 \%$ & -1.147 & 127 & $55: 72$ & -0.698 & $<0.0001$ \\
\hline 2007 & $0.30 \%$ & 0.754 & 166 & $86: 80$ & 0.240 & $-0.73 \%$ & -0.989 & 19 & $7: 12$ & -1.062 & $<0.0001$ \\
\hline
\end{tabular}

Panel B. Firms That Became Compliant by Adding Independent Directors to the Audit Committee, or Removing Inside Directors from the Audit Committee

\begin{tabular}{|c|c|c|c|c|c|c|c|c|c|c|c|}
\hline $\begin{array}{l}\text { All years } \\
\text { Pre-SOX } \\
\text { Post-SOX }\end{array}$ & $\begin{array}{l}0.55 \% \\
0.77 \% \\
0.36 \%\end{array}$ & $\begin{array}{l}3.813 \\
2.563 \\
2.841\end{array}$ & $\begin{array}{r}1,265 \\
521 \\
655\end{array}$ & $\begin{array}{l}689: 576 \\
322: 272 \\
367: 304\end{array}$ & $\begin{array}{l}4.306 \\
3.265 \\
2.386\end{array}$ & $\begin{array}{l}0.26 \% \\
0.38 \% \\
0.02 \% \text { ** }\end{array}$ & $\begin{array}{r}-0.078 \\
1.032 \\
0.075\end{array}$ & $\begin{array}{r}2,140 \\
1,239 \\
645\end{array}$ & $\begin{array}{l}\text { 049:1,095 } \\
728: 725 \\
321: 370\end{array}$ & $\begin{array}{r}2.425 \\
2.997 \\
-1.567\end{array}$ & $\begin{array}{l}<0.0001 \\
<0.0001 \\
<0.0001\end{array}$ \\
\hline 1998 & $0.06 \%$ & 0.325 & 94 & $47: 47$ & 0.371 & $0.20 \%$ & -1.588 & 81 & $32: 49$ & -0.050 & $<0.0001$ \\
\hline 1999 & $0.07 \%$ & 0.113 & 118 & $56: 62$ & -0.637 & $-0.24 \%$ & -1.844 & 420 & $178: 242$ & -1.228 & $<0.0001$ \\
\hline 2000 & $0.95 \%$ & 1.454 & 151 & $79: 72$ & 2.733 & $1.33 \%$ & 4.073 & 383 & $218: 165$ & 5.546 & $<0.0001$ \\
\hline 2001 & $1.49 \%$ & 2.451 & 158 & $98: 60$ & 3.113 & $0.50 \%$ & 0.499 & 355 & $184: 171$ & 1.803 & $<0.0001$ \\
\hline 2002 & $1.03 \%$ & 1.725 & 89 & $50: 39$ & 1.137 & $-0.20 \%$ & -0.680 & 256 & $119: 137$ & -0.594 & $<0.0001$ \\
\hline 2003 & $0.56 \%$ & 2.087 & 158 & $92: 66$ & 1.612 & $-0.08 \%$ & -1.233 & 219 & $101: 118$ & -1.641 & $<0.0001$ \\
\hline 2004 & $0.24 \%$ & 2.269 & 149 & $87: 62$ & 1.876 & $0.26 \%$ & 0.298 & 150 & $67: 83$ & 0.698 & 0.3716 \\
\hline 2005 & $0.26 \%$ & 1.255 & 97 & $50: 47$ & 1.299 & $0.16 \%$ & 0.768 & 130 & $69: 61$ & 0.266 & 0.0008 \\
\hline 2006 & $0.69 \%$ & 1.646 & 57 & $32: 25$ & 0.602 & $-0.07 \%$ & -1.147 & 127 & $55: 72$ & -0.698 & $<0.0001$ \\
\hline 2007 & $0.13 \%$ & 0.781 & 194 & $100: 94$ & 0.005 & $-0.73 \%$ & -0.989 & 19 & $7: 12$ & -1.062 & $<0.0001$ \\
\hline
\end{tabular}

(market-adjusted cumulative abnormal return (CAR)) is significantly positive for the post-SOX period (July 22, 2002-December 31, 2007) using a 3-day event window from day -1 to day $+1 .{ }^{14}$ Also, the market response is positive for the years 2002, 2003, 2004, 2005, 2006, and 2007. Similar results are obtained using longer event windows. The above findings are consistent with and supportive of

\footnotetext{
${ }^{14}$ Value-weighted market from CRSP is used as the market index. We also estimated the CARs based on the market model with similar results. See MacKinlay (1977) for a discussion of event studies.
} 
the event-study results of Chhaochharia and Grinstein (2007) and DeFond et al. (2005). Chhaochharia and Grinstein find that firms that were less compliant with the rules imposed by SOX and the exchanges earned more positive abnormal returns on the announcement of the rules. DeFond et al. document a positive stock market reaction when a director with accounting expertise is appointed to the audit committee.

Table 7 also summarizes the stock market's response to announcements of annual board elections by firms that continue being noncompliant with SOX's board independence requirements during 2002-2007. The market response is insignificantly different from 0 . Also, the difference in CARs of firms that go from being noncompliant to compliant and firms that stay noncompliant is significantly positive for the post-SOX period and for each of the years 2002, 2003, 2005, 2006, and 2007. The above evidence is consistent with the argument that SOX's board independence requirement perhaps played a positive role in enhancing firm performance.

Table 7 also compares the pre- and post-SOX announcement returns to the addition of independent directors to the audit committee or removal of inside directors from the audit committee. The above announcements will be better anticipated post-SOX compared to the pre-SOX period, since SOX mandated the independence requirement for audit committee members. Consistent with the above arguments, the pre-SOX announcement returns are significantly greater than post-SOX returns.

\section{Corporate Governance and CEO Turnover}

The preceding analysis focuses on the relation between governance and performance generally and in the specific case of SOX compliance. However, governance scholars and commentators suggest that governance is especially critical in imposing discipline and providing fresh leadership when the corporation is performing particularly poorly. For this reason, we study the relationship between governance, performance, and CEO turnover.

Using Compustat's ExecuComp database, we identify 1,951 CEO changes from 1998 to 2007. We hand-collect information from company press releases and press articles to determine whether the CEO departure was disciplinary or not. Table 8 documents the number of disciplinary and nondisciplinary CEO turnovers during this period. Our criteria for classifying CEO turnover as disciplinary or nondisciplinary are similar to those of Weisbach (1988), Gilson (1989), Huson, Parrino, and Starks (2001), and Farrell and Whidbee (2003). CEO turnover is classified as "nondisciplinary" if the CEO died, if the CEO was older than 63, if the change was the result of an announced transition plan, or if the CEO stayed on as chairman of the board for more than a year. CEO turnover is classified as "disciplinary" if the CEO resigned to pursue other interests, if the CEO was terminated, or if no specific reason is given. ${ }^{15}$

\footnotetext{
${ }^{15}$ For our purposes, distinguishing between the different subcategories within the "disciplinary" and "nondisciplinary" groups is not essential. There may be situations where a 65-year-old CEO leaves
} 
TABLE 8

Reasons for CEO Turnover

Table 8 presents the classifications for reasons why CEO turnover occurred in a specific year. LexisNexis archives were reviewed to determine the stated reason for why a CEO left the firm. CEO turnover data were obtained from Compustat's ExecuComp database. CEO Turnover is classified as "Nondisciplinary" if the CEO died, if the CEO was older than 63, if the change was the result of an announced transition plan, or if the CEO stayed on as chairman of the board. CEO Turnover is classified as "Disciplinary" if the CEO resigned to pursue other interests, if the CEO was fired, or if no specific reason is given

Reasons for CEO Turnover: 1998-2007

\begin{tabular}{|c|c|c|c|c|}
\hline & \\
\hline & Disciplinary & $\underline{\text { Nondisciplinary }}$ & Other & Total \\
\hline 1998 & 65 & 118 & 18 & 201 \\
\hline 1999 & 66 & 127 & 5 & 198 \\
\hline 2000 & 92 & 143 & 9 & 244 \\
\hline 2001 & 86 & 162 & 7 & 255 \\
\hline 2002 & 81 & 100 & 1 & 182 \\
\hline 2003 & 82 & 94 & 3 & 179 \\
\hline 2004 & 49 & 122 & 3 & 174 \\
\hline 2005 & 73 & 135 & 2 & 210 \\
\hline 2006 & 61 & 126 & 0 & 187 \\
\hline 2007 & 46 & 73 & 2 & 121 \\
\hline Total & 701 & 1,200 & 50 & 1,951 \\
\hline$\%$ of Total & $35.9 \%$ & $61.5 \%$ & $2.6 \%$ & $100 \%$ \\
\hline
\end{tabular}

We consider a multinomial logit regression with 3 independent categories: no turnover, disciplinary turnover, and nondisciplinary turnover. ${ }^{16}$ The dependent variable is equal to 0 if no turnover occurred in a firm-year, 1 if the turnover was disciplinary, and 2 if the turnover was nondisciplinary. We consider the last 2 years' stock return as the performance measure. We estimate the following baseline equation:

$$
\begin{aligned}
\text { Type of CEO Turnover }_{i, t}= & \text { Last } 2 \text { Years' Return }_{i, t} \\
& + \text { Last } 2 \text { Years' Industry Return }_{i, t} \\
& + \text { CEOOwn\% }_{i, t}+\text { FirmSize }_{i, t} \\
& + \text { CEOAge }_{i, t}+\text { CEOTenure }_{i, t}+\varepsilon a_{i, t} .
\end{aligned}
$$

The control variables are motivated by a substantial extant literature on performance and CEO turnover (e.g., see Huson et al. (2001), Farrell and Whidbee (2003), and Engel, Hayes, and Wang (2003)). To determine the role that governance plays in CEO turnover, we create an interactive variable that is equal to (Last 2 Years' Return $\times$ Governance). The reason behind this is that if the firm is performing adequately, good governance per se should not lead to CEO turnover; only when performance is poor do we expect better-governed firms to be more

as part of a succession plan and stays on as board chair for 12 months. This is a "nondisciplinary" turnover, regardless of which subcategory it gets classified in.

${ }^{16}$ We also considered a fixed effects logit estimator model. However, there are concerns regarding the bias of such an estimator. Greene (2004) documents that when the time periods in panel data are 5 or less (as is the case in this study), nonlinear estimation may produce coefficients that can be biased in the range of $32 \%-68 \%$. 
likely to replace the CEO. To measure this effect, we estimate the following modified version of equation (2a):

$$
\begin{aligned}
& \text { (2b) Type of CEO Turnover }{ }_{i, t}=\text { Last } 2 \text { Years' Return }{ }_{i, t} \\
& \text { + Last } 2 \text { Years' Industry Return }{ }_{i, t} \\
& + \text { Governance }_{i, t}+\left(\text { Governance }_{i t}\right.
\end{aligned}
$$

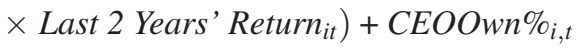

$$
\begin{aligned}
& + \text { FirmSize }_{i, t}+\text { CEOAge }_{i, t} \\
& + \text { CEOTenure }_{i, t}+\varepsilon b_{i, t} \text {. }
\end{aligned}
$$

Table 9 highlights the relation between different measures of governance and disciplinary CEO turnover. Panel A details the multinomial logit regression results for the determinants of disciplinary CEO turnover for the pre-2002 period. Consider first the baseline results without governance variables in the regression. The baseline results indicate that a firm's stock market returns during the previous 2 years, CEO stock ownership, and CEO tenure are significantly negatively

TABLE 9

\section{CEO Turnover-Governance Relation}

Table 9 presents the results from multinomial logistic regressions estimating the probability of CEO Turnover. The dependent variables are type of CEO turnover: 1 = Disciplinary turnover, 2 = Nondisciplinary turnover, $0=$ no turnover. Baseline results without governance are presented in the 1st column; all other columns present results including Governance and (Performance $\times$ Governance) variables. The other control variables are described in the text. Year dummy variables are included but are not shown. Panel A presents the results for disciplinary turnover for 1998-2001; Panel B presents the results for disciplinary turnover for 2003-2007; Panel C compares the Return t $_{2}$ to t_1 $\times$ Governance $_{t}$ interactive terms from Panels A and B across the 2 time periods, pre-SOX to post-SOX. Sample size refers to the entire sample for the par-

\begin{tabular}{|c|c|c|c|c|c|c|}
\hline & $\begin{array}{c}\text { Baseline } \\
\text { Performance } \\
\end{array}$ & Independence $t$ & DirectorOwnt & $\underline{\text { CEO-Duality } t}$ & G-Indext & E-Indext \\
\hline \multicolumn{7}{|c|}{ Panel A. Disciplinary Turnover: 1998-2001 } \\
\hline Intercept & $\begin{array}{l}-3.330^{\star \star \star} \\
(0.00)\end{array}$ & $\begin{array}{l}-3.268^{\star \star \star} \\
(0.00)\end{array}$ & $\begin{array}{l}-4.000^{\star \star \star} \\
(0.00)\end{array}$ & $\begin{array}{l}-3.310^{* * *} \\
(0.00)\end{array}$ & $\begin{array}{l}-2.978^{\star \star \star} \\
(0.00)\end{array}$ & $\begin{array}{l}-3.170^{\star \star \star} \\
(0.00)\end{array}$ \\
\hline Return $_{t-2}$ to $t-1$ & $\begin{array}{l}-1.576^{\star \star \star} \\
(0.00)\end{array}$ & $\begin{array}{c}-0.486 \\
(0.59)\end{array}$ & $\begin{array}{c}-2.443 \\
(0.27)\end{array}$ & $\begin{array}{c}-0.956^{*} \\
(0.06)\end{array}$ & $\begin{array}{r}-1.277 \\
(0.20)\end{array}$ & $\begin{array}{l}-1.483^{\star \star \star} \\
(0.01)\end{array}$ \\
\hline IndustryReturn $_{t-2}$ to $t-1$ & $\begin{array}{l}0.452 \\
(0.20)\end{array}$ & $\begin{array}{c}0.454 \\
(0.19)\end{array}$ & $\begin{array}{r}0.531 \\
(0.12)\end{array}$ & $\begin{array}{l}0.443 \\
(0.21)\end{array}$ & $\begin{array}{l}0.512 \\
(0.14)\end{array}$ & $\begin{array}{l}0.543 \\
(0.12)\end{array}$ \\
\hline Governance $_{t}$ & - & $\begin{array}{r}-0.140 \\
(0.22)\end{array}$ & $\begin{array}{r}0.045 \\
(0.42)\end{array}$ & 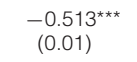 & $\begin{array}{r}-0.030 \\
(0.36)\end{array}$ & $\begin{array}{r}0.001 \\
(0.99)\end{array}$ \\
\hline $\begin{array}{l}\text { Return }_{t-2} \text { to } t-1 \times \\
\text { Governance } t\end{array}$ & - & $\begin{array}{c}-1.784^{*} \\
(0.07)\end{array}$ & $\begin{array}{c}-0.044^{*} \\
(0.08)\end{array}$ & $\begin{array}{c}-0.929 \\
(0.12)\end{array}$ & $\begin{array}{c}-0.004 \\
(0.85)\end{array}$ & $\begin{array}{c}-0.119 \\
(0.60)\end{array}$ \\
\hline CEOOwn\% $t$ & $\begin{array}{l}-0.119^{\star \star *} \\
(0.00)\end{array}$ & $\begin{array}{l}-0.121^{\star \star \star *} \\
(0.00)\end{array}$ & $\begin{array}{l}-0.121^{\text {*** }} \\
(0.00)\end{array}$ & $\begin{array}{l}-0.118^{* * *} \\
(0.00)\end{array}$ & $\begin{array}{l}-0.114^{* * *} \\
(0.00)\end{array}$ & $\begin{array}{l}-0.111^{\text {** }} \\
(0.00)\end{array}$ \\
\hline FirmSize $_{t}$ & $\begin{array}{l}-0.093^{*} \\
(0.09)\end{array}$ & $\begin{array}{r}-0.090 \\
(0.10)\end{array}$ & $\begin{array}{l}-0.094^{*} \\
(0.09)\end{array}$ & $\begin{array}{c}-0.059 \\
(0.30)\end{array}$ & $\begin{array}{r}-0.077 \\
(0.17)\end{array}$ & $\begin{array}{c}-0.082 \\
(0.14)\end{array}$ \\
\hline CEOAge $_{t-1}$ & $\begin{array}{r}0.020 \\
(0.12)\end{array}$ & $\begin{array}{r}0.020 \\
(0.11)\end{array}$ & $\begin{array}{l}0.021^{*} \\
(0.10)\end{array}$ & $\begin{array}{l}0.022^{*} \\
(0.08)\end{array}$ & $\begin{array}{r}0.015 \\
(0.23)\end{array}$ & $\begin{array}{c}0.014 \\
(0.27)\end{array}$ \\
\hline CEOTenure $_{t-1}$ & $\begin{array}{c}-0.025^{\star} \\
(0.07)\end{array}$ & $\begin{array}{c}-0.026^{*} \\
(0.07)\end{array}$ & $\begin{array}{c}-0.027^{\star} \\
(0.06)\end{array}$ & $\begin{array}{c}-0.025^{*} \\
(0.08)\end{array}$ & $\begin{array}{r}-0.020 \\
(0.15)\end{array}$ & $\begin{array}{c}-0.019 \\
(0.18)\end{array}$ \\
\hline $\begin{array}{l}\text { Years included } \\
\text { Sample size }\end{array}$ & $\begin{array}{c}1998-2001 \\
4,257\end{array}$ & $\begin{array}{c}1998-2001 \\
4,257\end{array}$ & $\begin{array}{c}1998-2001 \\
4,228\end{array}$ & $\begin{array}{c}1998-2001 \\
4,257\end{array}$ & $\begin{array}{c}1998-2001 \\
4,075\end{array}$ & $\begin{array}{c}1998-2001 \\
4,075\end{array}$ \\
\hline & & & & & (continued & $n$ next page) \\
\hline
\end{tabular}
ticular period, and not just to cases of disciplinary turnover and nondisciplinary turnover. ${ }^{\star * \star},{ }^{* *}$, and ${ }^{\star}$ indicate significance at the $1 \%, 5 \%$, and $10 \%$ levels, respectively.

Governance Variable 


\begin{tabular}{|c|c|c|c|c|c|c|}
\hline & & TABLE 9 (cC & ontinued) & & & \\
\hline & CEO & Turnover-Gove & ernance Rela & ation & & \\
\hline & & & Govern & nance Variable & & \\
\hline & $\begin{array}{c}\text { Baseline } \\
\text { Performance } \\
\end{array}$ & Independence $_{t}$ & $\underline{\text { DirectorOwn }}$ & $\underline{\text { CEO-Duality }}$ & G-Index $x_{t}$ & E-Indext \\
\hline Panel B. Disciplinary Turr & ver: 2003-2007 & & & & & \\
\hline Intercept & $\begin{array}{c}-0.978 \\
(0.98)\end{array}$ & $\begin{array}{c}-14.468 \\
(0.87)\end{array}$ & $\begin{array}{r}-11.677 \\
(0.90)\end{array}$ & $\begin{array}{c}-13.555 \\
(0.88)\end{array}$ & $\begin{array}{r}-12.921 \\
(0.88)\end{array}$ & $\begin{array}{c}-12.879 \\
(0.88)\end{array}$ \\
\hline Return $_{t-2}$ to $t-1$ & $\begin{array}{l}-3.510^{* * *} \\
(0.00)\end{array}$ & $\begin{array}{c}-0.712 \\
(0.83)\end{array}$ & $\begin{array}{c}-0.161 \\
(0.92)\end{array}$ & $\begin{array}{l}-2.942^{\star \star *} \\
(0.00)\end{array}$ & $\begin{array}{l}0.628 \\
(0.72)\end{array}$ & $\begin{array}{l}-2.194^{* *} \\
(0.03)\end{array}$ \\
\hline IndustryReturn $_{t-2}$ to $t-1$ & $\begin{array}{l}0.344^{* *} \\
(0.05)\end{array}$ & $\begin{array}{l}0.456 \\
(0.49)\end{array}$ & $\begin{array}{c}0.542 \\
(0.41)\end{array}$ & $\begin{array}{r}0.491 \\
(0.46)\end{array}$ & $\begin{array}{r}0.337 \\
(0.58)\end{array}$ & $\begin{array}{l}0.309 \\
(0.61)\end{array}$ \\
\hline Governance $_{t}$ & - & $\begin{array}{l}1.935 \\
(0.14)\end{array}$ & $\begin{array}{r}-0.121 \\
(0.26)\end{array}$ & $\begin{array}{c}-0.948 \\
(0.10)\end{array}$ & $\begin{array}{c}-0.009 \\
(0.83)\end{array}$ & $\begin{array}{r}-0.025 \\
(0.76)\end{array}$ \\
\hline $\begin{array}{l}\text { Return }_{t-2} \text { to } t-1 \times \\
\text { Governance } \\
\text { Gov }\end{array}$ & - & $\begin{array}{l}-3.726^{*} \\
(0.09)\end{array}$ & $\begin{array}{l}-0.248^{\star *} \\
(0.05)\end{array}$ & $\begin{array}{r}-1.407 \\
(0.21)\end{array}$ & $\begin{array}{l}-0.519^{\star \star \star} \\
(0.01)\end{array}$ & $\begin{array}{l}-0.777^{* *} \\
(0.03)\end{array}$ \\
\hline CEOOwn\%t & $\begin{array}{l}-0.205^{\star *} \\
(0.04)\end{array}$ & $\begin{array}{l}-0.230^{*} \\
(0.08)\end{array}$ & $\begin{array}{c}-0.221^{*} \\
(0.09)\end{array}$ & $\begin{array}{c}-0.206 \\
(0.11)\end{array}$ & $\begin{array}{l}-0.289^{\star \star} \\
(0.03)\end{array}$ & $\begin{array}{l}-0.285^{* *} \\
(0.04)\end{array}$ \\
\hline FirmSize $_{t}$ & $\begin{array}{c}0.079 \\
(0.14)\end{array}$ & $\begin{array}{r}0.074 \\
(0.23)\end{array}$ & $\begin{array}{r}0.101 \\
(0.10)\end{array}$ & $\begin{array}{l}0.145^{\star \star} \\
(0.02)\end{array}$ & $\begin{array}{l}0.103^{*} \\
(0.06)\end{array}$ & $\begin{array}{l}0.105^{\star} \\
(0.06)\end{array}$ \\
\hline CEOAge $_{t-1}$ & $\begin{array}{l}0.056^{\star * \star} \\
(0.00)\end{array}$ & $\begin{array}{l}0.068^{* * *} \\
(0.00)\end{array}$ & $\begin{array}{l}0.067^{\text {***}} \\
(0.00)\end{array}$ & $\begin{array}{l}0.078^{* * *} \\
(0.00)\end{array}$ & $\begin{array}{l}0.059^{\star * \star} \\
(0.00)\end{array}$ & $\begin{array}{l}0.058^{* \star *} \\
(0.00)\end{array}$ \\
\hline CEOTenure $_{t-1}$ & $\begin{array}{l}-0.030^{*} \\
(0.07)\end{array}$ & $\begin{array}{c}-0.036^{\star} \\
(0.07)\end{array}$ & $\begin{array}{l}-0.039^{* *} \\
(0.04)\end{array}$ & $\begin{array}{c}-0.029 \\
(0.12)\end{array}$ & $\begin{array}{c}-0.035^{\star} \\
(0.05)\end{array}$ & $\begin{array}{c}-0.034^{*} \\
(0.05)\end{array}$ \\
\hline $\begin{array}{l}\text { Years included } \\
\text { Sample size }\end{array}$ & $\begin{array}{l}2003-2007 \\
6,410\end{array}$ & $\begin{array}{c}2003-2007 \\
5,547\end{array}$ & $\begin{array}{c}2003-2007 \\
5,501\end{array}$ & $\begin{array}{c}2003-2007 \\
5,547\end{array}$ & $\begin{array}{c}2003-2007 \\
5,876\end{array}$ & $\begin{array}{c}2003-2007 \\
5,876\end{array}$ \\
\hline & & & Goverr & rnance Variable & & \\
\hline & & $\underline{\text { Independence }_{t}}$ & $\underline{\text { DirectorOwn }_{t}}$ & $\underline{\text { CEO-Duality } t}$ & $\underline{G-I n d e x_{t}}$ & E-Index $x_{t}$ \\
\hline Panel C. Comparison of $\square$ & sciplinary Turnove & er Interactive Term & & & & \\
\hline $\begin{array}{l}\text { Pre-SOX Return } \\
\text { Post-SOX Return } \\
\text { Post-2 to } t-^{-}\end{array}$ & $\begin{array}{l}\times \text { Governance }_{t} \\
\times \text { Governance }_{t}\end{array}$ & $\begin{array}{l}-1.784 \\
-3.726\end{array}$ & $\begin{array}{l}-0.044 \\
-0.248\end{array}$ & $\begin{array}{l}-0.929 \\
-1.407\end{array}$ & $\begin{array}{l}-0.004 \\
-0.519\end{array}$ & $\begin{array}{l}-0.119 \\
-0.777\end{array}$ \\
\hline Difference: Pre-SOX - Po & SOX & $\begin{array}{l}1.941^{\star \star \star} \\
(0.00)\end{array}$ & $\begin{array}{l}0.204^{*} \\
(0.08)\end{array}$ & $\begin{array}{l}0.478^{* *} \\
(0.02)\end{array}$ & $\begin{array}{l}0.515^{\star *} \\
(0.01)\end{array}$ & $\begin{array}{l}0.658^{* * \star} \\
(0.00)\end{array}$ \\
\hline
\end{tabular}

related to disciplinary CEO turnover; these findings are consistent with the prior literature noted above.

Does good governance have an impact on disciplinary CEO turnover directly, or is governance related to disciplinary turnover only in poorly performing companies? The results in Panel A of Table 9 shed light on this question for the pre-2002 period. Note that when the governance variables are included, the prior return variable is not significant in 3 of the 5 cases, suggesting that bad performance alone is not enough to lead to a change in senior management. Also, note that the governance variable by itself is statistically not significant in most cases. ${ }^{17}$ This suggests that good governance per se is not related to disciplinary turnover. The coefficient of the interactive term (Last 2 Years' Return $\times$ Governance) sheds light on the question of whether governance is related to disciplinary turnover only for poorly performing firms. The interactive term suggests that good governance as measured by the dollar value of the median director's stock ownership

\footnotetext{
${ }^{17}$ The exception is that when the CEO is also the chairman, he is less likely to experience disciplinary turnover.
} 
and the percentage of directors who are independent, increases the probability of disciplinary turnover for poorly performing firms. ${ }^{18,19}$

Panel B of Table 9 shows the results for disciplinary turnover in the post2002 period. The results in the 2003-2007 period are qualitatively unchanged from the results in 1998-2001, with the following exception: Both the GIM (2003) and BCF (2009) measures of good governance are negatively related to the probability of disciplinary turnover for poorly performing firms. This suggests that better-governed firms as measured by the GIM and BCF indices are less likely to experience disciplinary management turnover in spite of their poor performance. With respect to disciplining CEOs following poor firm performance, board independence appears to be an effective monitoring mechanism both before SOX and after SOX. It is important to note that we do not see the reversal post-SOX of the disciplining effect of board independence (in contrast to the performanceindependence relation discussed in Section IV). ${ }^{20}$

Panel C of Table 9 compares the coefficients of the interactive term (Last 2 Years' Return $\times$ Governance) post-SOX to pre-SOX for the different governance measures. The sensitivity of board independence to disciplinary turnover and board ownership to disciplinary turnover has increased significantly in the post-SOX period compared to the pre-SOX period (suggesting that independent directors and directors that own more stock are more likely to discipline the CEO of a poorly performing firm in the post-SOX period).

We also study the determinants of nondisciplinary CEO turnover. We do not expect any relation between good governance and nondisciplinary CEO turnover, both unconditionally and conditional on poor prior performance; untabulated results are consistent with this.

\section{Corporate Governance and M\&A Deals}

We find that given poor firm performance, the probability of disciplinary management turnover is positively correlated with stock ownership of board

\footnotetext{
${ }^{18}$ The finding of the probability of disciplinary CEO turnover (given poor prior firm performance) increasing with greater board independence is consistent with the extant literature (e.g., see Fich and Shivdasani (2006) and Weisbach (1988)).

${ }^{19}$ The economic importance of the dollar ownership of the median director is greater than board independence. We calculate the predicted probability of disciplinary and nondisciplinary turnover, using the coefficient estimates from Table 9. When all parameters are measured at their mean values, the probability of disciplinary turnover is $2.28 \%$ with the dollar ownership of the median director as the governance variable; this increases to $12.55 \%$ when the (Last 2 Years' Return $\times$ DirectorOwn) interaction term decreases by 1 standard deviation. The corresponding probabilities are $2.90 \%$ and $7.96 \%$ for board independence.

${ }^{20}$ Similar to footnote 19 , we again consider the economic importance of the dollar ownership of the median director, and board independence in disciplining CEOs of poorly performing firms. We calculate the predicted probability of disciplinary turnover, using the coefficient estimates from Table 9. We find a significant increase in the predicted probability of disciplinary turnover for both governance measures (dollar ownership of the median director and board independence). This suggests that the disciplinary role of independent directors and board holdings has increased subsequent to passage of SOX. The increased disciplinary role of independent directors subsequent to SOX is a potential explanation for the positive stock market response to companies becoming compliant to SOX's board independence requirement as noted above in Section V.
} 
members and board independence. Do governance mechanisms affect operational performance in other ways $?^{21}$ For example, previous studies have found that board independence affects corporate M\&As (see Byrd and Hickman (1992) and Cotter, Shivdasani, and Zenner (1997)).

Using the Securities Data Company (SDC) database, we identify whether or not each of our sample firms made an acquisition in a given firm-year. We consider a logit model where the dependent variable is equal to 1 if the sample firm makes an acquisition in a year, and 0 otherwise. Table 10 highlights the relation between different measures of governance and corporate acquisitions. Panel A details the logit regression results for the determinants of corporate acquisitions for the preSOX period. The key explanatory variable of interest is the Governance variable. We consider the 5 governance variables separately: Board Independence, Director Ownership, CEO Duality, GIM (2003) G-Index, and BCF (2009) E-Index. We include year and industry fixed effects.

TABLE 10

Impact of Corporate Governance on Making Acquisitions

Using the full sample of firms, Table 10 presents the results from a logit model estimating the probability of a firm making an acquisition relative to not making an acquisition. SDC data are used to identify whether or not a sample firm made an acquisition in a given year. The dependent variable is equal to 1 if the firm makes an acquisition, and 0 otherwise. Baseline results without governance are presented in the 1st column; all other columns present results including Governance variables. The other control variables are described in the text. Year dummy variables are included but are not shown. Intercepts and year and industry dummy variables are included but not presented. Panel A presents the results for 19982001; Panel B presents the results for disciplinary turnover for 2003-2007; Panel C presents the implied probabilities of acquisition for both sample periods and compares these probabilities across sample periods; and Panel D presents an event study of the cumulative abnormal returns (CARs) surrounding the acquisition announcement date within sample. In Panels $\mathrm{A}, \mathrm{B}$, and $\mathrm{C},{ }^{* \star *},{ }^{* *}$, and ${ }^{*}$ indicate significance at the $1 \%, 5 \%$, and $10 \%$ levels, respectively.

Governance Variable

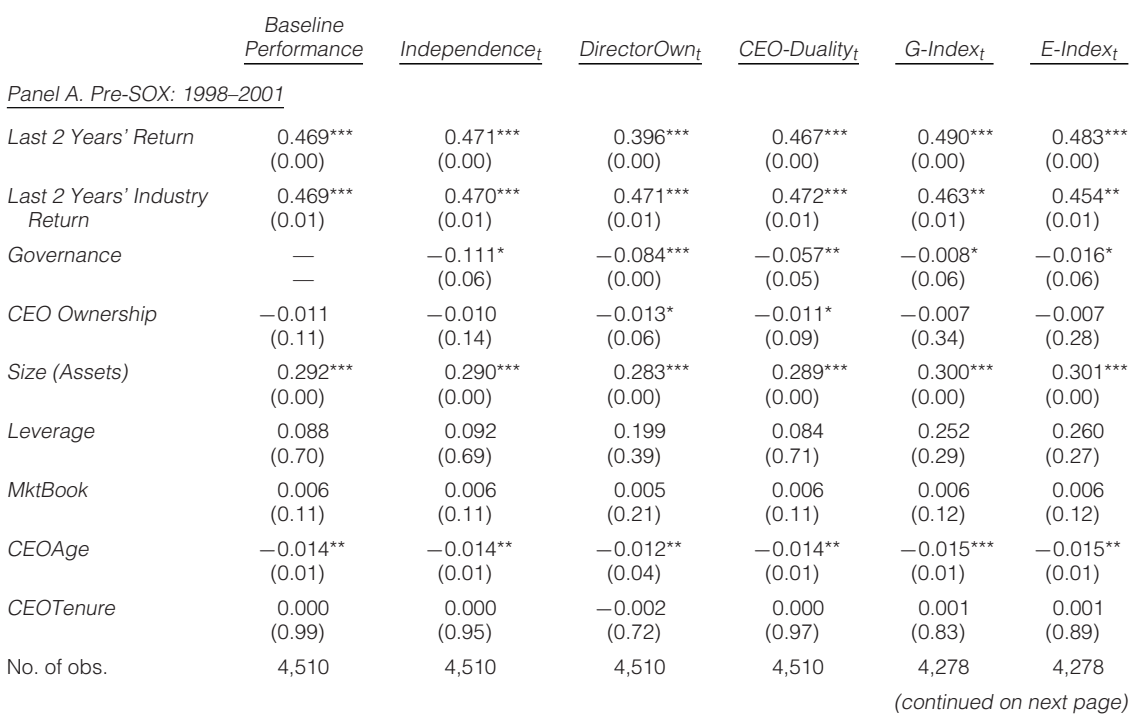

\footnotetext{
${ }^{21} \mathrm{We}$ are indebted to the referee for suggesting this to us, and for help in developing this section.
} 
TABLE 10 (continued)

Impact of Corporate Governance on Making Acquisitions

\begin{tabular}{|c|c|c|c|c|c|c|c|}
\hline & & \multirow[b]{2}{*}{$\begin{array}{c}\text { Baseline } \\
\text { Performance } \\
\end{array}$} & \multicolumn{5}{|c|}{ Governance Variable } \\
\hline & & & Independence ${ }_{t}$ & $\underline{\text { DirectorOwn }}$ & $\underline{\text { CEO-Duality } t}$ & G-Indext & E-Indext \\
\hline \multicolumn{8}{|c|}{ Panel B. Post-SOX: 2003-2007 } \\
\hline \multicolumn{2}{|c|}{ Last 2 Years' Return } & $\begin{array}{l}0.343^{\star \star} \\
(0.03)\end{array}$ & $\begin{array}{l}0.340^{\star *} \\
(0.03)\end{array}$ & $\begin{array}{l}0.261^{*} \\
(0.10)\end{array}$ & $\begin{array}{l}0.339^{* *} \\
(0.04)\end{array}$ & $\begin{array}{l}0.347^{\star \star} \\
(0.03)\end{array}$ & $\begin{array}{l}0.345^{\star *} \\
(0.03)\end{array}$ \\
\hline \multicolumn{2}{|c|}{$\begin{array}{l}\text { Last } 2 \text { Years' Industry } \\
\text { Return }\end{array}$} & $\begin{array}{c}0.246 \\
(0.22)\end{array}$ & $\begin{array}{r}0.254 \\
(0.20)\end{array}$ & $\begin{array}{c}0.239 \\
(0.23)\end{array}$ & $\begin{array}{c}0.258 \\
(0.20)\end{array}$ & $\begin{array}{c}0.260 \\
(0.20)\end{array}$ & $\begin{array}{l}0.259 \\
(0.20)\end{array}$ \\
\hline \multicolumn{2}{|l|}{ Governance } & - & $\begin{array}{l}-0.428^{*} \\
(0.08)\end{array}$ & $\begin{array}{l}-0.138^{* \star *} \\
(0.00)\end{array}$ & $\begin{array}{l}-0.206^{\star \star \star} \\
(0.01)\end{array}$ & $\begin{array}{c}-0.002^{*} \\
(0.09)\end{array}$ & $\begin{array}{c}-0.002 \\
(0.19)\end{array}$ \\
\hline \multicolumn{2}{|c|}{ CEO Ownership } & $\begin{array}{c}-0.018^{*} \\
(0.09)\end{array}$ & $\begin{array}{c}-0.019^{*} \\
(0.07)\end{array}$ & $\begin{array}{c}-0.018^{*} \\
(0.10)\end{array}$ & $\begin{array}{r}-0.019 \\
(0.10)\end{array}$ & $\begin{array}{c}-0.016 \\
(0.13)\end{array}$ & $\begin{array}{c}-0.016 \\
(0.14)\end{array}$ \\
\hline \multicolumn{2}{|l|}{ Size (Assets) } & $\begin{array}{l}0.204^{\star \star \star} \\
(0.00)\end{array}$ & $\begin{array}{l}0.209^{\star \star \star} \\
(0.00)\end{array}$ & $\begin{array}{l}0.190^{\star \star \star} \\
(0.00)\end{array}$ & $\begin{array}{l}0.211^{\star \star *} \\
(0.00)\end{array}$ & $\begin{array}{l}0.200^{* \star \star} \\
(0.00)\end{array}$ & $\begin{array}{l}0.200^{* * *} \\
(0.00)\end{array}$ \\
\hline \multicolumn{2}{|l|}{ Leverage } & $\begin{array}{c}0.109 \\
(0.62)\end{array}$ & $\begin{array}{l}0.113 \\
(0.61)\end{array}$ & $\begin{array}{l}0.254 \\
(0.25)\end{array}$ & $\begin{array}{l}0.134 \\
(0.56)\end{array}$ & $\begin{array}{l}0.089 \\
(0.69)\end{array}$ & $\begin{array}{l}0.088 \\
(0.70)\end{array}$ \\
\hline \multicolumn{2}{|l|}{ MktBook } & $\begin{array}{r}-0.004 \\
(0.30)\end{array}$ & $\begin{array}{r}-0.004 \\
(0.31)\end{array}$ & $\begin{array}{c}-0.006 \\
(0.19)\end{array}$ & $\begin{array}{c}-0.004 \\
(0.35)\end{array}$ & $\begin{array}{r}-0.004 \\
(0.31)\end{array}$ & $\begin{array}{c}-0.004 \\
(0.31)\end{array}$ \\
\hline \multicolumn{2}{|l|}{ CEOAge } & $\begin{array}{l}-0.024^{\star \star \star} \\
(0.00)\end{array}$ & $\begin{array}{l}-0.023^{\star * *} \\
(0.00)\end{array}$ & $\begin{array}{l}-0.021^{\star \star \star} \\
(0.00)\end{array}$ & $\begin{array}{l}-0.021^{\star \star \star} \\
(0.00)\end{array}$ & $\begin{array}{l}-0.019^{\star \star \star} \\
(0.00)\end{array}$ & $\begin{array}{l}-0.019^{\star * *} \\
(0.00)\end{array}$ \\
\hline \multicolumn{2}{|l|}{ CEOTenure } & $\begin{array}{l}0.010^{*} \\
(0.06)\end{array}$ & $\begin{array}{c}0.008 \\
(0.12)\end{array}$ & $\begin{array}{l}0.006 \\
(0.28)\end{array}$ & $\begin{array}{l}0.011^{\star *} \\
(0.04)\end{array}$ & $\begin{array}{l}0.008 \\
(0.14)\end{array}$ & $\begin{array}{c}0.008 \\
(0.14)\end{array}$ \\
\hline \multicolumn{2}{|l|}{ No. of obs. } & 5,059 & 5,059 & 5,059 & 5,059 & 4,923 & 4,923 \\
\hline \multicolumn{8}{|c|}{ Panel C. Implied Probability of Acquisitions } \\
\hline $\begin{array}{l}\text { Implied Probability } \\
\text { Pre-SOX Acquisition }\end{array}$ & $\begin{array}{l}\text { lity } \\
\text { uisition } \\
\text { fuisition }\end{array}$ & $\begin{array}{l}31.5 \% \\
30.0 \%\end{array}$ & $\begin{array}{l}31.3 \% \\
27.5 \%\end{array}$ & $\begin{array}{l}31.4 \% \\
29.0 \%\end{array}$ & $\begin{array}{l}31.6 \% \\
31.7 \%\end{array}$ & $\begin{array}{l}31.8 \% \\
32.0 \%\end{array}$ & $\begin{array}{l}31.8 \% \\
31.9 \%\end{array}$ \\
\hline \multirow{2}{*}{\multicolumn{2}{|c|}{$\begin{array}{l}\text { Difference in Probabilities: } \\
\text { Pre-SOX - Post-SOX }\end{array}$}} & $\begin{array}{l}1.5 \% \\
(0.02)^{\star \star}\end{array}$ & $\begin{array}{l}3.8 \% \\
(0.00)^{\star \star \star}\end{array}$ & $\begin{array}{l}2.4 \% \\
(0.00)^{\star \star \star}\end{array}$ & $\begin{array}{r}-0.1 \% \\
(0.14)\end{array}$ & $\begin{array}{r}-0.2 \% \\
(0.19)\end{array}$ & $\begin{array}{r}-0.1 \% \\
(0.12)\end{array}$ \\
\hline & & & \multicolumn{5}{|c|}{ Market-Adjusted Returns } \\
\hline & $\begin{array}{l}\text { Sample } \\
\text { Size }\end{array}$ & $\begin{array}{l}\text { Positive: } \\
\text { Negative } \\
\text { Returns }\end{array}$ & CAR & z-Statistic & $p$-Value & $\begin{array}{c}\text { Non- } \\
\text { parametric } \\
\text { Statistic }\end{array}$ & $p$-Value \\
\hline Window & 1 & 2 & 3 & 4 & 5 & 6 & 7 \\
\hline \multicolumn{8}{|c|}{ Panel D. Acquisition Announcement Abnormal Returns (CARs) for Sample Firms during 1998-2007 } \\
\hline $\begin{array}{l}\text { Equal-Weight } \\
(-1,+1) \\
(-3,+3) \\
(-3,+10) \\
(-5,+5) \\
(-10,+10)\end{array}$ & $\begin{array}{r}\text { Index } \\
4,815 \\
4,815 \\
4,815 \\
4,815 \\
4,815\end{array}$ & $\begin{array}{l}2,399: 2,416 \\
2,360: 2,455 \\
2,309: 2,506 \\
2,346: 2,469 \\
2,252: 2,563\end{array}$ & $\begin{array}{l}-0.21 \% \\
-0.25 \% \\
-0.15 \% \\
-0.12 \% \\
-0.56 \%\end{array}$ & $\begin{array}{l}3.654 \\
2.225 \\
1.072 \\
0.523 \\
3.145\end{array}$ & $\begin{array}{l}0.0003 \\
0.0261 \\
0.2838 \\
0.6010 \\
0.0017\end{array}$ & $\begin{array}{l}4.431 \\
4.184 \\
4.129 \\
4.167 \\
3.710\end{array}$ & $\begin{array}{r}<0.0001 \\
<0.0001 \\
<0.0001 \\
<0.0001 \\
0.0003\end{array}$ \\
\hline $\begin{array}{l}\text { Value-Weight } \\
(-1,+1) \\
(-3,+3) \\
(-3,+10) \\
(-5,+5) \\
(-10,+10)\end{array}$ & $\begin{array}{l}\text { Index } \\
4,815 \\
4,815 \\
4,815 \\
4,815 \\
4,815\end{array}$ & $\begin{array}{l}2,328: 2,487 \\
2,332: 2,483 \\
2,338: 2,477 \\
2,305: 2,510 \\
2,361: 2,454\end{array}$ & $\begin{array}{l}-0.31 \% \\
-0.47 \% \\
-0.41 \% \\
-0.49 \% \\
-0.41 \%\end{array}$ & $\begin{array}{l}5.798 \\
5.791 \\
3.576 \\
4.785 \\
2.942\end{array}$ & $\begin{array}{r}<0.0001 \\
<0.0001 \\
0.0004 \\
<0.0001 \\
0.0033\end{array}$ & $\begin{array}{l}4.148 \\
3.772 \\
3.138 \\
3.297 \\
2.781\end{array}$ & $\begin{array}{r}<0.0001 \\
0.0002 \\
0.0019 \\
0.0011 \\
0.0057\end{array}$ \\
\hline
\end{tabular}

The results show that firms with greater board independence and greater director ownership are less likely to make acquisitions. Since public acquisitions are associated with negative returns for acquiring shareholders (e.g., see Moeller, Schlingemann, and Stulz (2005)), this suggests another channel by which greater board independence and director ownership positively impact a firm's operational 
performance. $^{22}$ With regard to the GIM (2003) and BCF (2009) governance measures, the negative coefficient implies that GIM and BCF measures of good governance are positively related to the probability of a value-destroying activity, namely, acquisitions. (Recall that lower values of the GIM and BCF indices are associated with better governance.)

Panel B of Table 10 details the logit regression results for the determinants of corporate acquisitions for the post-SOX period. Again, the results show that firms with greater board independence and greater director ownership are less likely to make acquisitions. With regard to the GIM (2003) and BCF (2009) governance measures, the negative coefficient again implies that GIM and BCF measures of good governance are positively related to the probability of a value-destroying activity, namely, acquisitions, in the post-SOX period.

Panel $\mathrm{C}$ of Table 10 summarizes the difference in implied acquisition probabilities pre- and post-SOX for the different governance measures. Board independence and director ownership are associated with a statistically and economically significant decrease in acquisition probabilities in the post-SOX period compared to the pre-SOX period.

\section{Conclusions}

We study the impact of SOX on the relationship between corporate governance and company performance. A significant part of SOX and other exchange requirements increases the role of independent board members. Given that prior academic research suggests there is no positive relationship between board independence and firm performance, the above regulatory efforts are especially notable.

We find a shift in the relationship between board independence and firm performance after 2002. Prior to 2002, we document a negative relationship between board independence and operating performance. After 2002, we find a positive relationship between independence and operating performance. We find this result is driven by firms that increase their number of independent directors. An event study provides independent evidence supportive of the above results (specifically, when a company goes from being noncompliant to being compliant with SOX's board independence requirement, the market response is significantly positive). Why might SOX be related to this positive performance? SOX and the listing standards impose new responsibilities on firms' directors, such as regular meetings of the independent directors, approval of director nominations by independent directors, and approval of CEO compensation by independent directors. As a consequence of these policies, boards began including more independent directors, and perhaps the independent directors became more engaged in the firm's governance processes. For example, we find that firms with greater board independence (and

\footnotetext{
${ }^{22}$ Panel D of Table 10 summarizes the market-adjusted CAR surrounding the acquisition announcement date for different event windows for the sample firms in this study. Consistent with prior literature, the CARs in our sample are significantly negative, suggesting that these acquisitions are viewed negatively by investors.
} 
stock ownership of board members) are less likely to engage in a value-destroying activity, namely, acquisitions.

We find a consistent positive performance-governance relationship for director ownership. On average, the median director's stock ownership is $45 \%$ greater in 2003-2007 than it was in 1998-2001, and the relationship between director ownership and firm performance is consistently positive for both subperiods; this relationship is robust to a battery of specification tests. Hence, this study proposes a governance measure, namely, dollar ownership of the board members, that is simple, intuitive, less prone to measurement error, and not subject to the problem of weighting a multitude of governance provisions in constructing a governance index. Consideration of this governance measure by future researchers would enhance the comparability of research findings with more robust progress in governance research.

\section{References}

Adams, R., and D. Ferreira. "A Theory of Friendly Boards.” Journal of Finance, 62 (2007), 217-250.

Agrawal, A., and C. R. Knoeber. "Firm Performance and Mechanisms to Control Agency Problems between Managers and Shareholders." Journal of Financial and Quantitative Analysis, 31 (1996), 377-397.

Altman, E. I. "Financial Ratios, Discriminant Analysis and the Prediction of Corporate Bankruptcy." Journal of Finance, 23 (1968), 589-609.

Ashbaugh-Skaife, H.; D. W. Collins; and R. LaFond. "The Effects of Corporate Governance on Firms' Credit Ratings.” Journal of Accounting and Economics, 42 (2006), 203-243.

Barber, B., and J. Lyon. "Detecting Abnormal Operating Performance: The Empirical Power and Specification of Test Statistics.” Journal of Financial Economics, 41 (1996), 359-400.

Bebchuk, L.; A. Cohen; and A. Ferrell. "What Matters in Corporate Governance?" Review of Financial Studies, 22 (2009), 783-827.

Berkowitz, D.; M. Caner; and Y. Fang. “Are 'Nearly Exogenous Instruments' Reliable?" Economics Letters, 2008, 101 (2008), 20-23.

Bhagat, S., and B. Black. "The Non-Correlation between Board Independence and Long-Term Firm Performance.” Journal of Corporation Law, 27 (2002), 231-274.

Bhagat, S., and B. Bolton. "Corporate Governance and Firm Performance." Journal of Corporate Finance, 14 (2008), 257-273.

Bhagat, S.; B. Bolton; and R. Romano. "The Promise and Peril of Corporate Governance Indices." Columbia Law Review, 108 (2008), 1803-1882.

Bhagat, S., and R. Jefferis, Jr. The Econometrics of Corporate Governance Studies. Cambridge, MA: MIT Press (2002).

Bhagat, S., and H. Tookes. "Voluntary and Mandatory Skin in the Game: Understanding Outside Directors' Stock Holdings.” European Journal of Finance, 18 (2012), 191-207.

Bound, J.; D. A. Jaeger; and R. M. Baker. "Problems with Instrumental Variables Estimation When the Correlation between the Instruments and the Endogenous Explanatory Variable Is Weak." Journal of the American Statistical Association, 90 (1995), 443-450.

Brickley, J. A.; J. L. Coles; and G. Jarrell. "Leadership Structure: Separating the CEO and Chairman of the Board." Journal of Corporate Finance, 3 (1997), 189-220.

Brochet, F. "Information Content of Insider Trades Before and After the Sarbanes-Oxley Act." Accounting Review, 85 (2010), 419-446.

Brown, L. D., and M. L. Caylor. "Corporate Governance and Firm Valuation." Journal of Accounting and Public Policy, 25 (2006), 409-434.

Byrd, J., and K. Hickman. "Do Outside Directors Monitor Managers?" Journal of Financial Economics, 32 (1992), 195-221.

Chao, J. C., and N. R. Swanson. "Consistent Estimation with Large Number of Weak Instruments." Econometrica, 73 (2005), 1673-1692.

Chenhall, R. H., and F. Moers. "The Issue of Endogeneity Within Theory-Based, Quantitative Management Accounting Research.” European Accounting Review, 16 (2007), 173-195.

Chhaochharia, V., and Y. Grinstein. "Corporate Governance and Firm Value: The Impact of the 2002 Governance Rules.” Journal of Finance, 62 (2007), 1789-1825. 
Coles, J. L.; N. D. Daniel; and L. Naveen. “Boards: Does One Size Fit All?” Journal of Financial Economics, 79 (2008), 329-356.

Core, J. E.; W. R. Guay; T. O. Rusticus. "Does Weak Governance Cause Weak Stock Returns? An Examination of Firm Operating Performance and Investors' Expectations." Journal of Finance, 61 (2006), 655-687.

Core, J. E.; R. W. Holthausen; and D. F. Larcker. "Corporate Governance, Chief Executive Officer Compensation, and Firm Performance.” Journal of Financial Economics, 51 (1999), 371-406.

Cotter, J.; A. Shivdasani; and M. Zenner. "Do Independent Directors Enhance Target Shareholder Wealth During Tender Offers?” Journal of Financial Economics, 43 (1997), 195-218.

Cragg, J. G., and S. G. Donald. "Testing Identifiability and Specification in Instrumental Variable Models." Econometric Theory, 9 (1993), 222-240.

Cremers, K. J. M., and V. B. Nair. "Governance Mechanisms and Equity Prices.” Journal of Finance, 60 (2005), 2859-2894.

Davidson, R., and J. G. MacKinnon. Estimation and Inference in Econometrics. New York, NY: Oxford University Press (2004).

DeFond, M. L.; R. N. Hann; and X. Hu. "Does the Market Value Financial Expertise on Audit Committees of Boards of Directors?" Journal of Accounting Research, 43 (2005), 153-173.

Demsetz, H. "The Structure of Ownership and the Theory of the Firm." Journal of Law and Economics, 26 (1983), 375-390.

Duchin, R.; J. G. Matsusaka; and O. Ozbas. "When Are Outside Directors Effective?" Journal of Financial Economics, 96 (2010), 195-214.

Dufour, J. "Some Impossibility Theorems in Econometrics, with Applications to Structural and Dynamic Models." Econometrica, 65 (1997), 1365-1389.

Engel, E.; R. M. Hayes; and X. Wang. "CEO Turnover and Properties of Accounting Information." Journal of Accounting and Economics, 36 (2003), 197-226.

Farrell, K. A., and D. A. Whidbee. "The Impact of Firm Performance Expectations on CEO Turnover and Replacement Decisions.” Journal of Accounting and Economics, 36 (2003), 165-196.

Fich, E. M., and A. Shivdasani. “Are Busy Boards Effective Monitors?” Journal of Finance, 61 (2006), $689-724$.

Gibbons, R., and K. J. Murphy. "Optimal Incentive Contracts in the Presence of Career Concerns: Theory and Evidence." Journal of Political Economy, 100 (1992), 468-505.

Gillan, S. L.; J. C. Hartzell; and L. T. Starks. "Explaining Corporate Governance: Boards, Bylaws, and Charter Provisions." Working Paper, University of Georgia (2003).

Gilson, S. C. "Management Turnover and Financial Distress." Journal of Financial Economics, 25 (1989), 241-262.

Gompers, P. A.; J. L. Ishii; and A. Metrick. "Corporate Governance and Equity Prices.” Quarterly Journal of Economics, 118 (2003), 107-155.

Graham, J. R. "Debt and the Marginal Tax Rate." Journal of Financial Economics, 41 (1996), 41-73.

Greene, W. H. "The Behavior of the Fixed Effects Estimator in Nonlinear Models." Econometrics Journal, 7 (2004), 98-119.

Guggenberger, P. "Finite-Sample Evidence Suggesting a Heavy Tail Problem of the Generalized Empirical Likelihood Estimator." Working Paper, University of California at Los Angeles (2005).

Hahn, J., and J. A. Hausman. "A New Specification Test for the Validity of Instrumental Variables." Econometrica, 70 (2002), 163-189.

Hall, A.; G. Rudebusch; and D. Wilcox. "Judging Instrument Relevance in Instrumental Variables Estimation.” International Economic Review, 37 (1996), 283-298.

Hallock, K. F. "Reciprocally Interlocking Boards of Directors and Executive Compensation.” Journal of Financial and Quantitative Analysis, 32 (1997), 331-344.

Hansen, L. P. "Large Sample Properties of Generalized Method of Moments Estimators." Econometrica, 50 (1982), 1029-1054.

Harris, M., and A. Raviv. "A Theory of Board Control and Size." Review of Financial Studies, 21 (2008), 1797-1832.

Hausman, J. A. "Specification Tests in Econometrics.” Econometrica, 46 (1978), 1251-1271.

Hermalin, B. E. "Trends in Corporate Governance.” Journal of Finance, 60 (2005), 2351-2384.

Hermalin, B. E., and M. S. Weisbach. "The Effects of Board Composition and Direct Incentives on Firm Performance.” Financial Management, 20 (1991), 101-112.

Hermalin, B. E., and M. S. Weisbach. "Endogenously Chosen Boards of Directors and Their Monitoring of the CEO." American Economic Review, 88 (1998), 96-118.

Himmelberg, C. P.; R. G. Hubbard; and D. Palia. "Understanding the Determinants of Managerial Ownership and the Link between Ownership and Performance." Journal of Financial Economics, 53 (1999), 353-384.

Huson, M. R.; R. Parrino; and L. T. Starks. "Internal Monitoring Mechanisms and CEO Turnover: A Long-Term Perspective.” Journal of Finance, 54 (2001), 2265-2297. 
Johnson, S.; T. C. Moorman; and S. Sorescu. "A Reexamination of Corporate Governance and Equity Prices." Review of Financial Studies, 22 (2009), 4753-4786.

Kennedy, P. A Guide to Econometrics, 5th ed. Cambridge, MA: MIT Press (2003).

Krishnaswami, S., and V. Subramanian. "Information Asymmetry, Valuation, and the Corporate SpinOff Decision.” Journal of Financial Economics, 53 (1999), 73-112.

Larcker, D. F., and S. A. Richardson. "Fees Paid to Audit Firms, Accrual Choices, and Corporate Governance." Journal of Accounting Research, 42 (2004), 625-658.

Laux, V. "Board Independence and CEO Turnover." Journal of Accounting Research, 46 (2008), $137-171$.

Lehn, K.; S. Patro; and M. Zhao. "Governance Indices and Valuation Multiples: Which Causes Which?” Journal of Corporate Finance, 13 (2007), 907-928.

Linck, J. S.; J. M. Netter; and T. Yang. "The Determinants of Board Structure.” Journal of Financial Economics, 87 (2008), 308-328.

MacKinlay, A. C. "Event Studies in Economics and Finance." Journal of Economic Literature, 35 (1997), 13-39.

Masulis, R. W., and S. Mobbs. "Are All Inside Directors the Same? Evidence from the External Directorship Market.” Journal of Finance, 66 (2011), 823-872.

Milanovic, B. "Do More Unequal Countries Redistribute More? Does the Median Voter Hypothesis Hold?" World Bank Policy Research Working Paper Series, Carnegie Endowment for International Peace (2004).

Moeller, S. B.; F. P. Schlingemann; and R. M. Stulz. "Wealth Destruction on a Massive Scale? A Study of Acquiring-Firm Returns in the Recent Merger Wave.” Journal of Finance, 60 (2005), 757-782.

Nelson, C. R., and R. Startz. "Some Further Results on the Exact Small Sample Properties of the Instrumental Variables Estimator." Econometrica, 58 (1990), 967-976.

Palia, D. "The Endogeneity of Managerial Compensation in Firm Valuation: A Solution." Review of Financial Studies, 14 (2001), 735-764.

Petersen, M. A. "Estimating Standard Errors in Finance Panel Data Sets: Comparing Approaches." Review of Financial Studies, 22 (2009), 435-480.

Raheja, C. G. "Determinants of Board Size and Composition: A Theory of Corporate Boards." Journal of Financial and Quantitative Analysis, 40 (2005), 283-306.

Rogers, W. "Regression Standard Errors in Clustered Samples." Stata Technical Bulletin, 13 (1993), 19-23.

Sargan, J. D. “The Estimation of Economic Relationships Using Instrumental Variables.” Econometrica, 26 (1958), 393-415.

Shea, J. "Instrument Relevance in Multivariate Linear Models: A Simple Measure." Review of Economics and Statistics, 79 (1997), 348-352.

Shleifer, A., and K. M. Murphy. "Persuasion in Politics." American Economic Association Papers and Proceedings, 94 (2004), 435-439.

Stock, J. H.; J. Wright; and M. Yogo. "A Survey of Weak Instruments and Weak Identification in Generalized Method of Moments." Journal of Business and Economic Statistics, 20 (2002), $518-529$.

Stock, J. H., and M. Yogo. "Testing for Weak Instruments in Linear IV Regression.” In Identification and Inference for Econometric Models: Essays in Honor of Thomas J. Rothenberg, D. W. K. Andrews and J. H. Stock, eds. Cambridge, UK: Cambridge University Press (2004).

Weisbach, M. S. "Outside Directors and CEO Turnover." Journal of Financial Economics, 20 (1988), $432-460$.

Westphal, J. D., and P. Khanna. "Keeping Directors in Line: Social Distancing as a Control Mechanism in the Corporate Elite." Administrative Science Quarterly, 48 (2003), 361-398.

Wooldridge, J. M. Econometric Analysis of Cross Section and Panel Data. Cambridge, MA: MIT Press (2002).

Yermack, D. "Higher Market Valuation for Firms with a Small Board of Directors." Journal of Financial Economics, 40 (1996), 185-211. 